Review Article

\title{
Effects of gene therapy on cardiovascular symptoms of lysosomal storage diseases
}

Edina Poletto $^{1,2}$ (D), Gabriela Pasqualim ${ }^{1,2}$, Roberto Giugliani ${ }^{1,2,3,4}$ (D), Ursula Matte ${ }^{1,2,4}$ and Guilherme Baldo ${ }^{1,2,5}$ iD

${ }^{1}$ Gene Therapy Center, Hospital de Clínicas de Porto Alegre, Porto Alegre, RS, Brazil.

${ }^{2}$ Postgraduate Program in Genetics and Molecular Biology, Universidade Federal do Rio Grande do Sul, Porto Alegre, RS, Brazil.

${ }^{3}$ Medical Genetics Service, Hospital de Clínicas de Porto Alegre, Porto Alegre, RS, Brazil.

${ }^{4}$ Department of Genetics, Universidade Federal do Rio Grande do Sul, Porto Alegre, RS, Brazil.

${ }^{5}$ Department of Physiology, Universidade Federal do Rio Grande do Sul, Porto Alegre, RS, Brazil.

\begin{abstract}
Lysosomal storage diseases (LSDs) are inherited conditions caused by impaired lysosomal function and consequent substrate storage, leading to a range of clinical manifestations, including cardiovascular disease. This may lead to significant symptoms and even cardiac failure, which is an important cause of death among patients. Currently available treatments do not completely correct cardiac involvement in the LSDs. Gene therapy has been tested as a therapeutic alternative with promising results for the heart disease. In this review, we present the results of different approaches of gene therapy for LSDs, mainly in animal models, and its effects in the heart, focusing on protocols with cardiac functional analysis.
\end{abstract}

Keywords: Lysosomal storage disease, gene therapy, cardiovascular disease, animal models, heart.

Received: April 27, 2018; Accepted: November 28, 2018.

\section{Introduction}

Lysosomal storage diseases (LSDs) are a group of inherited disorders characterized by impairment of lysosomal function due to accumulation of undegraded or partially degraded metabolites. There are more than 50 disorders mainly caused by deficient lysosomal enzymes, but also by decreased function of membrane proteins or non-enzymatic soluble proteins, ultimately resulting in substrate accumulation, reduced lysosomal trafficking and cellular dysfunction (Platt et al., 2012; Boustany, 2013).

Even though LSDs are monogenic, the phenotypes may vary considerably among individuals with the same disease depending on the mutation profile - while some alleles produce proteins with residual activity, others result in complete loss of function. Hence, the clinical spectrum amongst LSDs varies largely accordingly to the residual protein function in addition to the type of metabolite stored (Segatori, 2014).

LSDs are multisystemic and progressive, normally non evident at birth but leading to premature death if not treated (Platt et al., 2012). Common symptoms shared by

Send correspondence to Ursula Matte. Gene Therapy Center, Hospital de Clínicas de Porto Alegre, Rua Ramiro Barcelos 2350, 90035-903 Porto Alegre, RS, Brazil. E-mail: umatte@ hcpa.edu.br most of them are organomegaly, cognitive impairment, skeletal defects and coarse facial features, all at variable degrees (Ortolano et al., 2014). Some have cardiovascular involvement, with cardiac failure generally being one of the main causes of death (Braunlin et al., 2011).

In this context, defects in the glycogen, lipid or glycosaminoglycan metabolism lead to disturbed energy production, altered cellular homeostasis and consequent cardiomyopathy (Guertl et al., 2000). Diseases such as glycosphyngolipidoses, mucopolyssacharidoses, and of glycogen storage, normally present significant cardiovascular manifestations, including hypertrophic and dilated cardiomyopathy, coronary artery disease, and valvular disease (Linhart and Elliott, 2007) (Table 1).

Current treatments for LSDs, such as intravenous enzyme replacement therapy (ERT) and hematopoietic stem cell transplantation (HSCT), normally have satisfactory response in some visceral organs such as the liver and spleen, but are insufficient to correct specific tissue manifestations, such as in brain, bones and some cardiovascular symptoms. The central nervous system (CNS) is hard to reach due to the blood brain barrier, which is mostly impermeable to exogenous enzymes and most drug therapies that use conventional administration routes (Parenti et al., 2013). Bones normally respond poorly to treatments due to low vascu- 
Poletto et al.

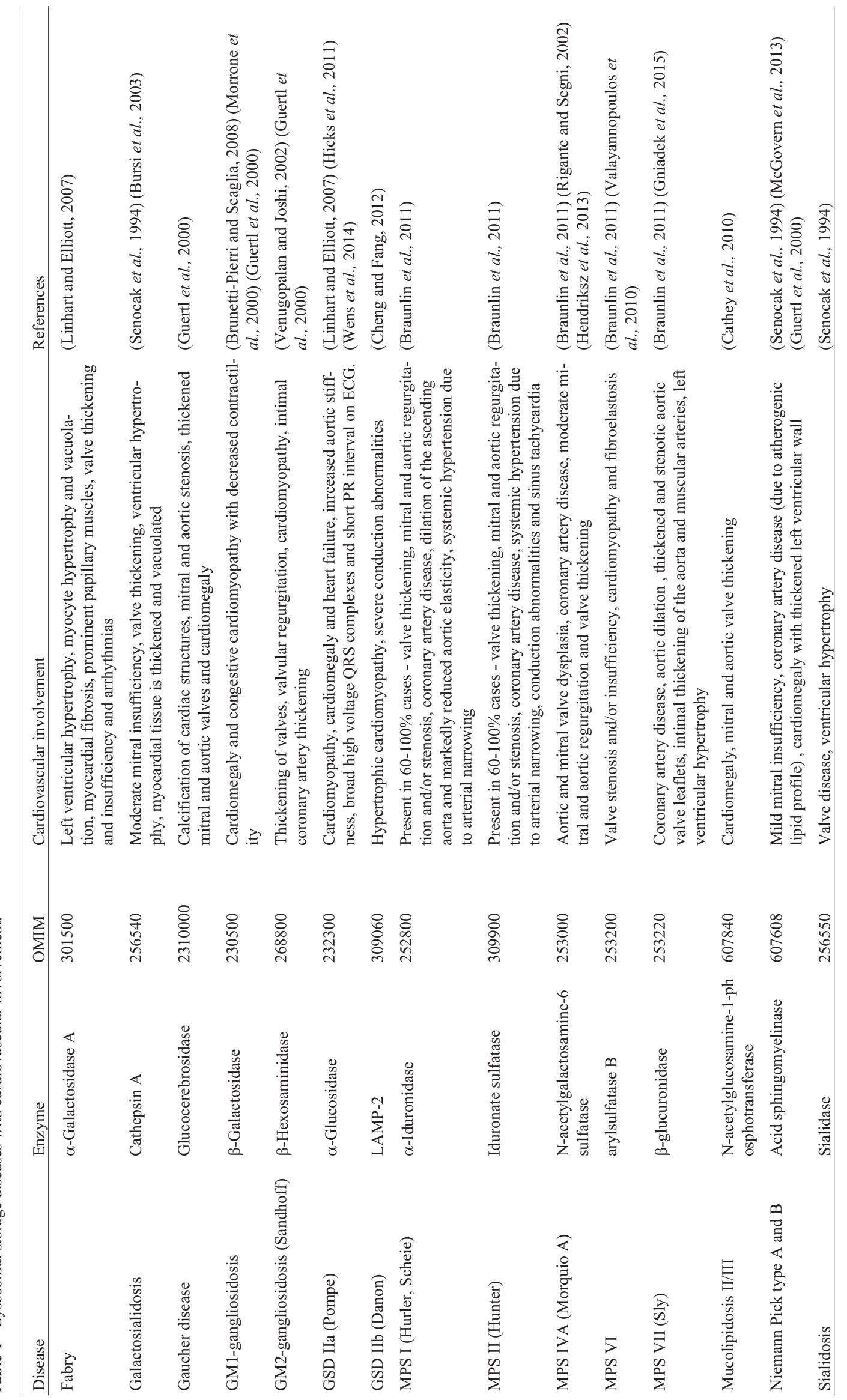


larization, preventing the therapy to reach the affected area (Clarke and Hollak, 2015). Accordingly, as paradoxical as it may seem, cardiovascular structures as heart valves and aorta are also poorly vascularized, making them less responsive to treatments as well (Ma et al., 2007; Brands et al., 2013).

Most therapeutic approaches for LSDs are based on the event of cross-correction, in which cells can uptake extracellular lysosomal enzymes - administered exogenously or secreted by other cells - via mannose-6-phosphate (M6P) receptor and route them to the lysosomes, where the $\mathrm{pH}$ is acid and they can work normally (Sands and Davidson, 2006). In addition, it has been suggested that a recovery of only about $10 \%$ of enzyme activity would be enough to prevent or even revert most clinical manifestations (Leinekugel et al., 1992; Sands and Davidson 2006). Hence, modifying few cells would be enough to achieve a satisfying therapy for some LSDs and gene therapy is an approach that meets this idea.

\section{Gene therapy}

The sole purpose of gene therapy is to genetically modify targeted cells (Cotrim and Baum, 2008). Gene therapy is typically performed to correct mutated genes or to add functional copies of a required sequence, although it can also be used to provide new functions to the cells or even to silence overexpressing genes. Its different approaches depend on the pathological condition and targeted tissue and studies have been conducted for genetic, psychiatric, immune and cardiovascular diseases and cancer (Collins and Thrasher, 2015).

For the LSDs, gene therapy seems to have great potential. As opposed to ERT, the promise of gene therapy is that a good gene transfer method could bypass the bloodbrain barrier and modify brain cells, which in turn would produce the missing enzyme and possibly brake the CNS manifestations (Zhang et al., 2011).

There are different ways to deliver the gene of interest into cells: using viral or non-viral vectors and also performing gene transfer in vivo or ex vivo. The simplest way to deliver a gene is cloning it on a plasmid, together with regulatory sequences that ensure its transcription, and then inject it into a cell - this, however, is poorly efficient. Although non-viral vectors are very safe, due to their episomal conformation and very low immunogenicity, their main drawback is the low transfection efficiency. Many strategies have been developed to enhance non-viral gene delivery (Wang et al., 2013; Jayant et al., 2016), as electroporation, gene gun, hydrodynamic injection, nanotechnology-based carriers (Schuh et al., 2016), DNA minicircle (Osborn et al., 2011), and transposons (Aronovich et al., 2009), but all still present low efficiency of transfection and specific procedure limitations.

Viral vectors are recombinant viruses lacking sequences for auto replication, while preserving the ones re- quired to transduce cells, plus the gene of interest. Therefore, they still express surface proteins specific to certain cell types, making the transgene uptake possible through cellular endocytosis, but they fail in replicating and lysing cells (Wang and Gao, 2014). The process of transducing cells is normally highly efficient, making viral vectors the first choice of many studies. Currently, most used are retrovirus (RV), lentivirus (LV) adenovirus (AV), and adeno-associated virus (AAV).

Retroviral and lentiviral vectors are classicaly integrative vectors, i.e., they integrate the transgene into the genome of proliferating cells (and also quiescent cells in the case of lentivirus), which ensures persistent expression and stability. On the other hand, it also brings the risk of insertional mutagenesis by possibly activating oncogenes or disrupting tumor suppressor genes. Integration-deficient LVs are being developed to surpass this limitation, but its efficiency is yet to be determined (Alfranca et al., 2018).

Alternatively, adenoviruses can transduce both quiescent and proliferating cells and do not integrate the sequence into the genome, residing episomally in the cell nucleus. Although this prevents insertional mutagenesis, the expression of the transgene is transient and eventually lost. Another disadvantage of AV is the very strong immunogenicity, leading to possible severe adverse effects in the host (Wold and Toth, 2013).

Adeno-associated viruses have strong tropism for certain cell types due to their capsid serotype, guaranteeing directed treatment to specific tissues (Wu et al., 2006). The apparent lack of immunogenicity and the stable episomal conformation of the DNA, which promotes long-term transgene expression with minimal risk of insertional mutagenesis, are other vantages of this vector. Nevertheless, AAV vectors only enable the insertion of small transgene cassetes, limited to less than 5Kb (Salganik et al., 2015).

Viral vectors are constantly engineered to develop safer versions, as by removing sequences that interact with neighbour genes (as the Long Terminal Repeat, LTR), or preventing the insertional mutagenesis by mutating the integrase or, yet, using gene editing tools to direct the integration site (Wang and Gao, 2014).

\section{Gene therapy in LSD}

There are many studies in the literature about gene therapy in LSDs with different types of vectors, administration protocols and/or auxiliary drugs. Since the cardiovascular system is one of the major systems affected in several LSDs and not responsive to current treatments, it has also been targeted in some gene therapy studies. Therefore, reports that address gene therapy effect on the cardiac system, most still in preclinical stage, are summarized over the next sections. 


\section{Glycogen Storage Diseases (GSD)}

\section{Pompe Disease (GSD Type II a)}

Pompe disease, or Glycogen Storage Disease type II a (GSD-IIa), is caused by deficiency of lysosomal acid $\alpha-1-$ 4-glucosidase (GAA). In this disorder, glycogen accumulates mainly within the heart and muscles, among other organs. Cardiac disease is characterized by hypertrophic cardiomyopathy, increased aortic stiffness (Wens et al., 2014), broad high voltage QRS complexes, and short PR interval on electrocardiogram (ECG) (Linhart and Elliott, 2007).

Gene therapy for GSD-IIa has been extensively studied, with many different approaches focusing mainly on amelioration of skeletal and cardiac muscles. There is one study describing the use of lentivirus with positive results in the heart, as reduction of glycogen storage (Kyosen et al., 2010), although the majority of published papers describe efforts to improve transduction efficiency and control of immune response using either adenovirus or AAV, as discussed further.

In 1998, a gene therapy protocol "was developed" using transmyocardial injection with adenoviral vector with GAA (AV-GAA) in newborn rats (Pauly et al., 1998). GAA activity was measured in whole heart extracts at day 7 , when the animals were euthanized, and resulted in 10 -fold the value of the control groups (non-treated or mock treated). According to the authors, no deleterious effects were observed in any groups. Subsequently, analysis of vector sequences in different organs showed that the GAA activity observed in the heart was due to transduced cells in the liver, which would function as a factory of enzyme that could be uptaken by other organs (Pauly et al., 2001). This result inspired other studies that focus on transducing efficiently the liver or a muscle to produce enough enzyme for the whole body.

Similar outcomes using adenovirus were also seen in posterior study using young (Ding et al., 2001) and old (Xu et al., 2005) GAA-knockout (GAA-KO) mice. In spite of the initial promising results, reduced glycogen clearance in muscles of older animals was noticed. Among other possibilities, one speculation is that the fusion of endosomes containing GAA with pre-existing lysosomes full of glycogen may impair the enzyme acitivity as the GAA-KO mice age, resulting in deficient activity of active and correctly processed GAA.

Regarding therapy with AAV vectors, newborn mice receiving the vector with cytomegalovirus promoter (CMV) AAV1-CMV-GAA intravenously resulted in initial supraphysiologic levels of GAA in hearts, with consistent drop in enzyme levels as mice aged (Mah et al., 2005). Posteriorly, heart function was evaluated by electrocardiogram and AAV1-treated animals presented significant prolonged PR interval, with values in between untreated GAA-KO and wild-type mice. Moreover, left ventricular mass was very similar to the wild-type age-matched controls. Although biochemical, histological and functional analysis showed improvement in the cardiac tissue after AAV1 therapy, it only partially corrected the pathology (Mah et al., 2007).

Many AAV vectors, with different promoters and serotypes, proved to be safe and efficient in increasing GAA activity and reducing glycogen deposits in hearts of GAA-KO mice (Table 2), as AAV2 (Fraites et al., 2002), AAV7-MCK (MCK - Muscle Creatine Kinase Promoter) (Sun et al., 2005a), AAV2/8 (Franco et al., 2005; Sun et al., 2005b; Wang et al., 2014), AAV8/DC190 (DC190 - Human Serum Albumin Promoter) (Ziegler et al., 2008) and AAV9-DES (DES - Desmin Promoter) (Falk et al., 2015), this last resulting also in elongation of PR interval, increased ejection fraction and reduction in left ventricular mass. A combination between AV and AAV also showed to be effective in long-term GAA production in heart, even when administered in the gastrocnemius muscle (Sun et al., 2003).

One of the major drawbacks of viral vector use is the immune response elicited against the vector itself or against the transgene, induced by the viral-mediated expression of GAA which compromises the effectiveness of the therapy, since anti-GAA antibodies probably inhibit cross-correction of peripheral tissues. Xu et al. (2004) illustrated this by using GAA-KO/SCID (SCID - Severe Combined Immunodeficiency) mice to analyse the response to AV-GAA therapy in an immunodeficient environment and concluded that the lack of anti-GAA antibodies found in GAA-KO/SCID mice resulted in higher GAA activity and glycogen clearance was maintained longer than previous studies using immunocompetent GAA-KO mice (Xu et al., 2004). To work around this issue, many strategies have been used: pre-treatments with GAA to induce tolerization (Cresawn et al., 2005) or with anti-CD4 to inhibit antibody formation (Han et al., 2015); adaptations in the vector design, using codon-optimized GAA driven by nonviral promoters (Kiang et al., 2006; Doerfler et al., 2016). Interestingly, it has been shown that a pre-treatment with gene therapy using AAV2/8 may prevent IgG antibody formation later with ERT, acting as a pre-conditioning therapy that could enhance the effectiveness of the ERT (Han et al., 2017).

Recently, the use of salmeterol, a $\beta 2$-receptor agonist, as an adjuvant has been tested, since this drug may enhance the expression of cation-independent mannose-6-phosphate receptor (CI-M6PR) and therefore could improve the response to ERT or gene therapy in heart tissues (Han et al., 2016). The treatment did enhance cardiac response to gene therapy, but further studies should be performed before adding the drug as adjunctive therapy.

Besides the comparison between different vectors or pre-treatment options, alternative administration routes are constantly being analysed as well. Intramyocardial (Pauly et al., 1998; Fraites et al., 2002), intramuscular (Sun et al., 


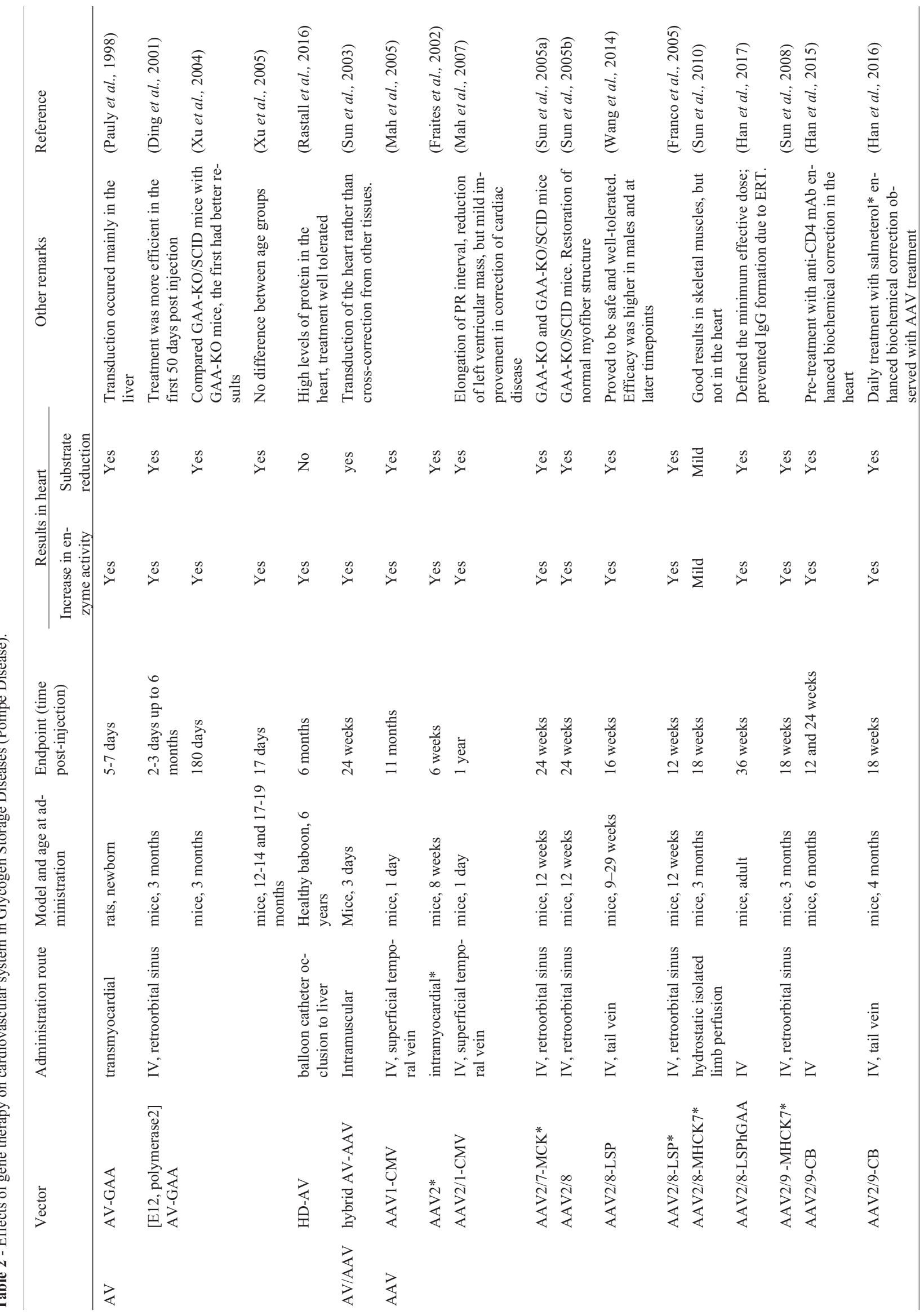


Poletto et al.

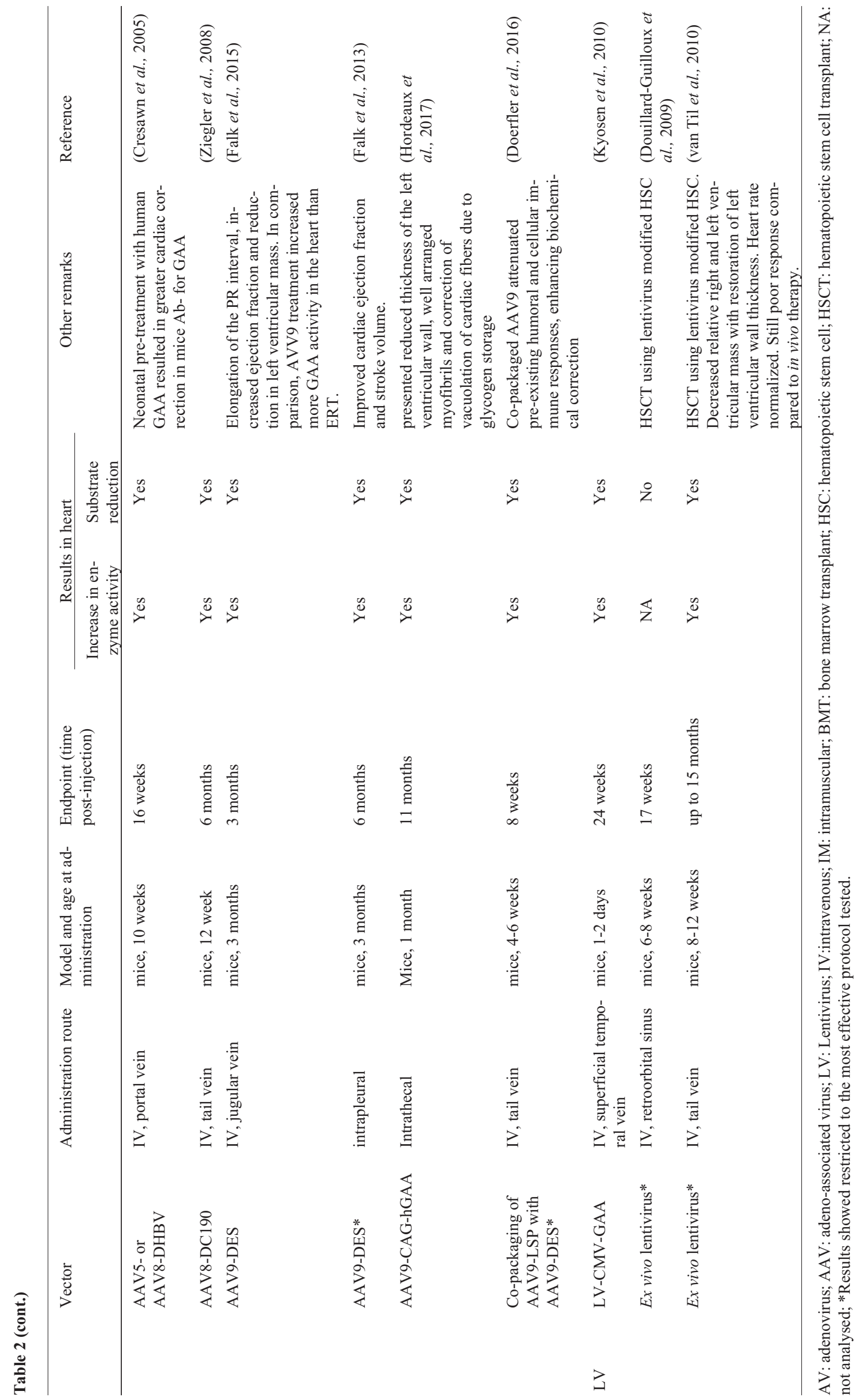


2003, 2010), intrapleural (Falk et al., 2013) and intrathecal (Hordeaux et al., 2017) administrations were already tested and showed transduction of various tissues. Of these, intramuscular administration was seen to be restricted to the injection site (Sun et al., 2003, 2010), while intrathecal injection of AAV9 vector surprisingly resulted in reduction of substrate storage in the heart and consequently reduction of left ventricular wall thickness (Hordeaux et al., 2017). Intrapleural administration of AAV9 also ameliorated cardiac symptoms, with improvement in ejection fraction and stroke volume (Falk et al., 2013).

Contrarily to some other LSDs, hematopoietic stem cell transplant is not an effective approach in GSD-II (Watson et al., 1986) unless hematopoietic stem cells (HSC) are modified ex vivo to produce supraphysiologic enzyme levels enough to cross-correct peripheral tissues (van Til et al., 2010). Therefore, this strategy was tested in a couple of studies using lentiviral vectors, in which HSC were harvested from GAA-KO mice donors, modified in vitro and transplanted intravenously in GAA-KO mice recipients after sublethal irradiation. The first study (Douillard-Guilloux et al., 2009) showed no significant improvement in the heart of treated animals though the latter (van Til et al., 2010) presented amelioration of echocardiographic findings, with decrease in relative right and left ventricular mass, and reconstitution of GAA activity with robust glycogen reduction in the heart. Even though some improvement was observed, other strategies have proven to be more effective in the context of GSD-II.

Finally, to evaluate safety and efficacy in other animal models, Rastall et al. (2016) used baboons, which underwent balloon catheter administration of helper dependent adenovirus (HD-AV) expressing GAA. Both animals treated presented high levels of GAA in the heart, as observed in Western Blot analysis and enzymatic assay.

\section{Mucopolysaccharidoses (MPS)}

\section{MPS Type I}

MPS I (Hurler, Scheie or Hurler-Scheie diseases) is caused by mutations in the IDUA gene, resulting in deficiency of $\alpha$-L-iduronidase (IDUA), an enzyme required in the degradation pathway of glycosaminoglycans (GAGs) heparan and dermatan sulphate. Common cardiovascular manifestations include dilated cardiomyopathy, cardiac valve abnormalities as valve thickening, stenosis and regurgitation, coronary artery disease due to diffuse intimal proliferation from GAG deposition and dilatation of the aorta with reduced aortic elasticity (Braunlin et al., 2011). Moreover, cardiovascular complications, as heart failure, sudden death from arrhythmias and coronary occlusion, are the main cause of mortality (Braunlin et al., 2011).

Numerous studies were conducted using gene therapy to treat murine, canine and feline models of MPS I (Table 3), which also present cardiac disease, although with small differences (Jordan et al., 2005; Braunlin et al., 2006; Sleeper et al., 2008). However, most of these studies focus on the CNS and neurological manifestations, limiting cardiovascular analysis only to IDUA activity and GAG deposition in the heart. Some papers describe the use of lentivirus (Di Domenico et al., 2005; Kobayashi et al., 2005; Ou et al., 2016), adeno-associated virus (Hartung et $a l ., 2004$ ) and non-viral DNA minicircle vectors (Osborn et al., 2011), Sleeping Beauty transposon (Aronovich et al., 2009), and microcapsules containing recombinant cells overexpressing IDUA (Baldo et al., 2012; Lizzi Lagranha et al., 2017) to treat MPS I. Results from all of them show increased IDUA activity and reduced GAG storage in heart after the treatment.

Ma et al. (2007) treated six-week-old MPS I mice intravenously with an RV expressing canine IDUA under control of the liver-specific Human $\alpha_{1}$-Antitrypsin Promoter (hAAT-cIDUA-WPRE) and the Woodchuck Hepatitis Virus Post-Transcriptional Regulatory Element (WPRE), resulting in mild improvement in cardiovascular structures in animals expressing stable enzyme activity in the serum. Lysosomal storage was significantly reduced in aortic valves and cardiac parenchyma, but not in the aorta. The aorta of treated mice remained dilated and with elastic fiber fragmentations (Ma et al., 2007). Accordingly, in another study (Herati et al., 2008), even though the enzyme activity was $37 \%$ of normal in the aorta of RV treated mice, GAG levels remained high in this tissue, and $75 \%$ of treated animals developed aortic insufficiency due to aortic dilatation.

On the other hand, a study using newborn MPS I dogs and RV hAAT-cIDUA-WPRE gene therapy showed great improvement in cardiac disease on the treated group, with reduction of aortic diameter, mitral valve thickening and elastic fiber fragmentation (Traas et al., 2007). The enzyme activity detected in the heart and the aorta was $30 \%$ and $20 \%$ of normal, respectively, and the lysosomal storage was reduced in both tissues. Furthermore, in MPS I cats (Hinderer et al., 2014), AAV8 vector expressing feline IDUA by a liver-specific promoter was administered. Aorta and myocardium exhibited total correction of storage lesions and aortic valves had near complete resolution in animals with constant enzyme expression. In addition, collagen structures of the fibrosa layer of the valves from treated cats were very similar to the normal group. One cat had a decline in IDUA activity and, consequently, had the worst outcome, but antibodies against IDUA were not found in ELISA tests.

In another study, MPS I mice treated with high-dose RV hAAT-cIDUA-WPRE showed promising outcomes: the echocardiograms in treated mice were completely normal - no significant changes in wall thickness, left ventricular mass index or end-diastolic left ventricular chamber size - and none had aortic dilatation or aortic insufficiency, features found on untreated MPS I mice or treated with 
Poletto et al.

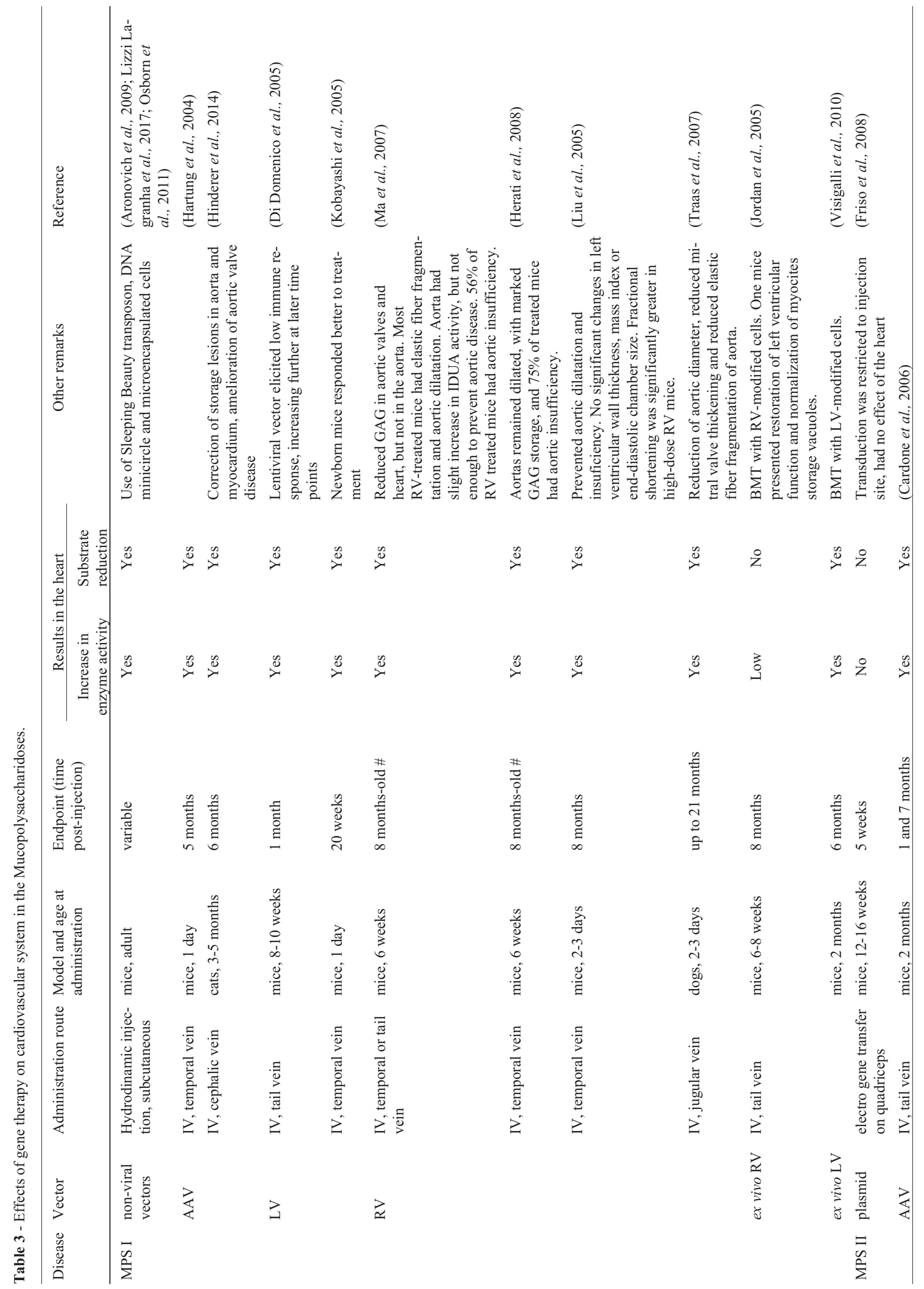




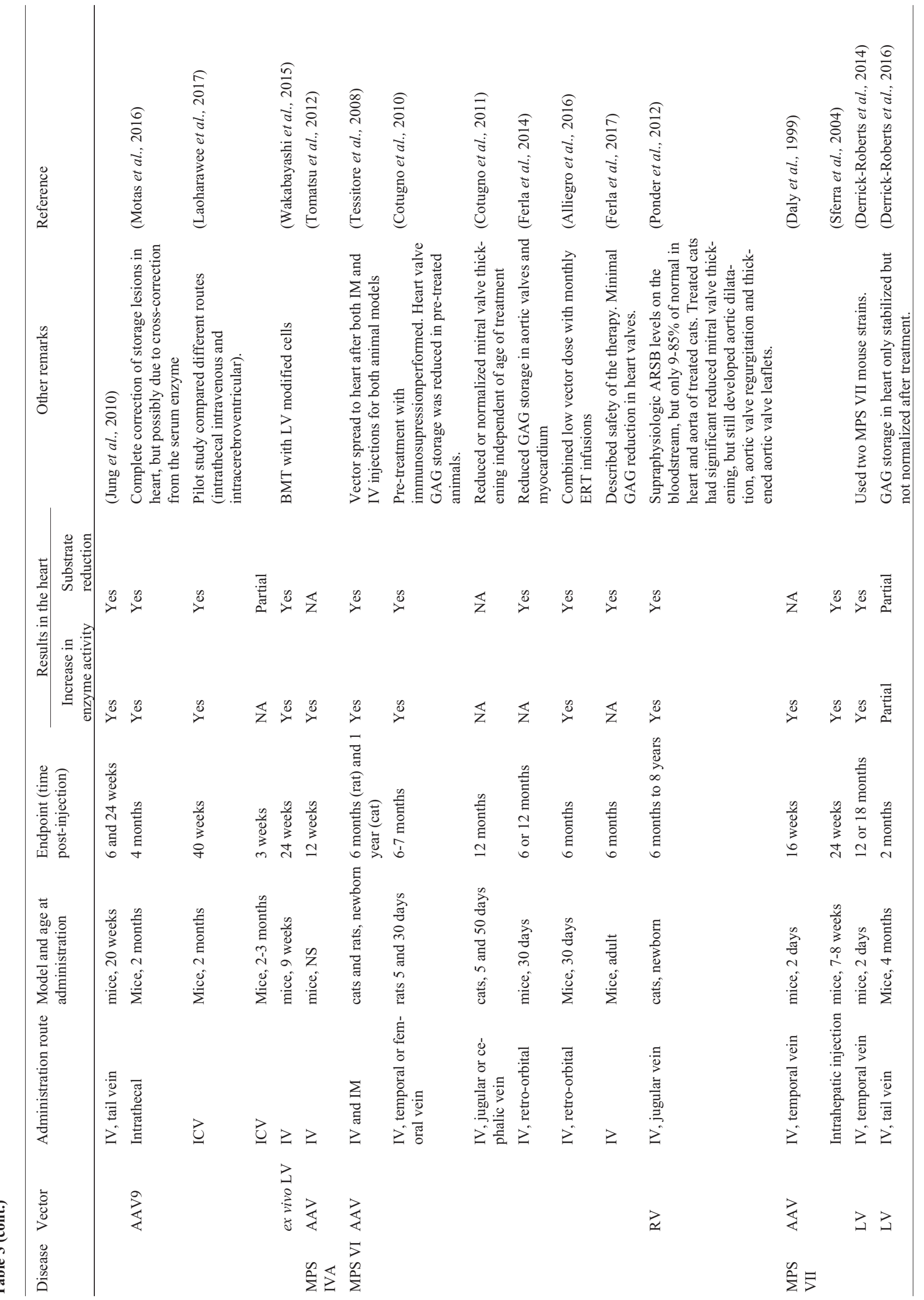




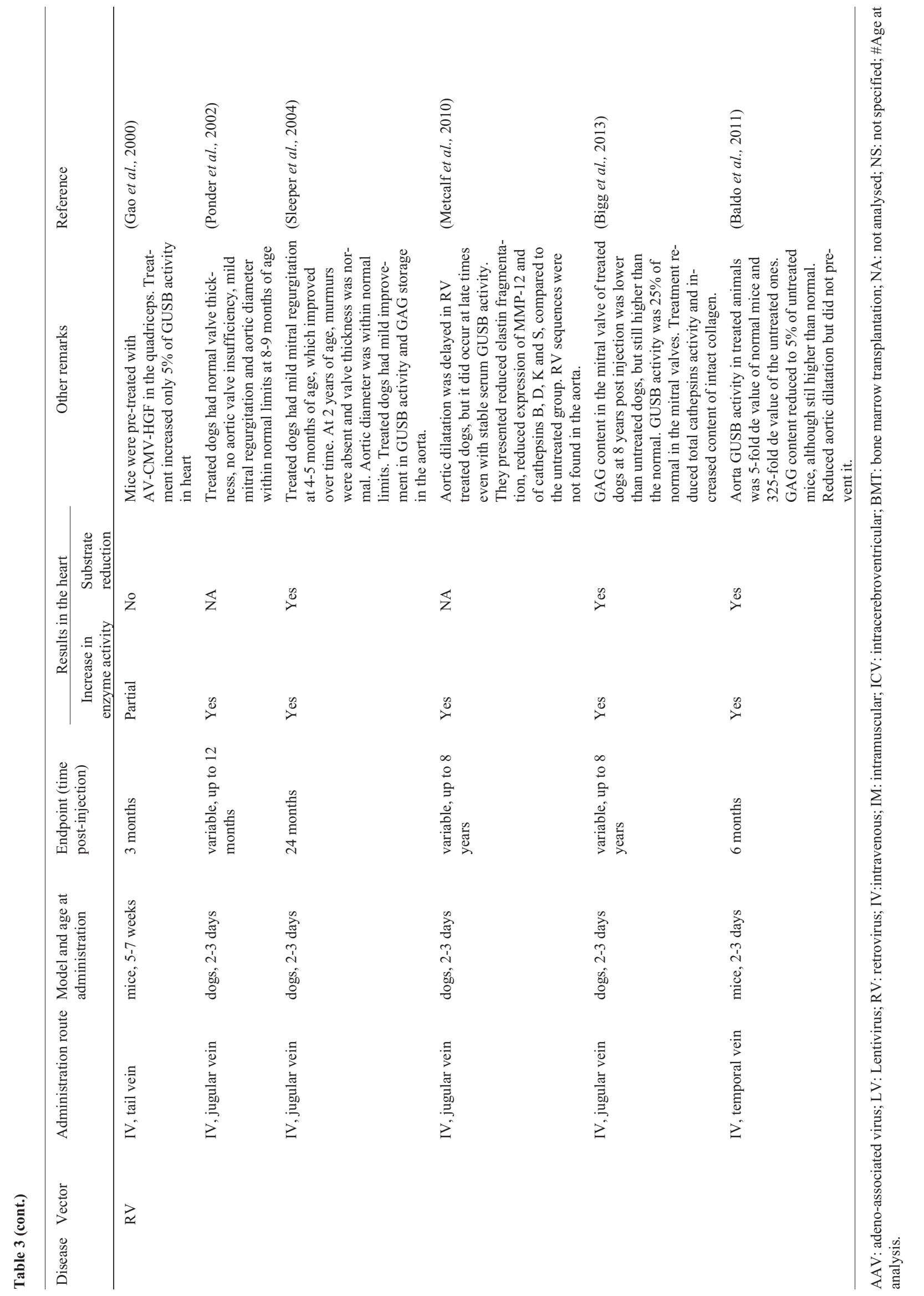


lower RV doses (Liu et al., 2005). Additionally, lysosomal storage was absent from most regions in the aorta, mitral valve and myocardium of high dose RV treated animals, while it was present in the untreated group. High dose RV had 9-fold normal IDUA activity in heart and aorta. Hexosaminidase levels - which is a lysosomal enzyme with activity elevated due to MPS I secondary effects - was also normal, as did GAG levels in both organs. Interestingly, low-dose RV treated MPS I mice had $14 \%$ of normal IDUA activity in the aorta and it was insufficient to prevent cardiac disease, which may be explained by the unequal distribution of the enzyme throughout the structure (Liu et al., 2005).

Finally, few studies have used HSCT together with gene therapy, modifying the cells ex vivo to overexpress IDUA using viral vectors. Initially, in a study using a retroviral vector containing IDUA, only one treated mouse out of ten had mild cardiac improvement (Jordan et al., 2005). On the other hand, Visigalli et al. (2010) compared normal and modified HSC from MPS I donor to overexpress IDUA through lentivirus transduction. Plasma IDUA levels were much higher with modified HSC than in other groups and resulted in almost complete absence of lysosomal storage and other pathological conditions, while the transplant with normal HSC only offered mild improvement in comparison. This study highlights the fact that the complete resolution of the cardiac manifestations is very much dependent on the supraphysiologic levels of the enzyme, otherwise the treatment would not be as effective in hard-to-target organs (Visigalli et al., 2010).

\section{MPS Type II}

MPS II (Hunter disease) is an X-linked recessive disease caused by iduronate 2 -sulfatase (IDS) deficiency, leading to dermatan and heparan sulfate accumulation. Cardiac involvement is very similar to MPS I, but MPS II patients may also present conduction abnormalities and sinus tachycardia (Braunlin et al., 2011).

Gene therapy research for MPS II started in the decade of 1990 with in vitro modification of cells to express IDS based on viral vectors (Braun et al., 1993, 1996 Whitley et al., 1996; Di Francesco et al., 1997; Stroncek et al., 1999) and non-viral approaches in 2002 (Tomanin et al., 2002). Only in 2006 the first paper describing in vivo gene therapy of MPS II was published (Cardone et al., 2006), following the creation of the mouse model. The transduction was directed to the liver, using AAV2/8-TBG-IDS vector. In the latter, increased IDS activity was observed in the heart, as was clearance of lysosomal GAG deposition. Other analyses regarding cardiovascular function were not performed. These findings were also seen in a posterior study using a different mouse model and a similar vector (Jung et al., 2010). On the contrary, when a plasmid vector was administered in the quadriceps muscle followed by electro-gene transfer, IDS activity was not detected in vis- ceral organs, including heart, remaining restricted to the injection area (Friso et al., 2008). Three recent studies described CNS-directed administration of AAV9 in MPS II mice, resulting in increased IDS activity in heart and correction of storage lesions (Laoharawee et al., 2017; Motas et al., 2016) or partial reduction of GAG storage (Hinderer et al., 2016). Since the organ did not present sufficient AAV copies, the occurrence of cross-correction of IDS deficiency by uptake of the enzyme from circulation was suggested.

Similar to an MPS I study already discussed (Visigalli et al., 2010), Wakabayashi et al. (2015) have shown that ex vivo HSC gene therapy using lentiviral vector improves the biochemical abnormalities of MPS II mice, including heart, with increased IDS activity to 3 -fold higher than normal and normalized lysosomal GAG content. Unfortunately, echocardiographic analysis was not performed (Wakabayashi et al., 2015).

\section{MPS Type IV A}

MPS IV A (Morquio A disease) is caused by keratan and chondroitin sulfate deposition due to deficiency of the lysosomal enzyme N-acetylgalactosamine-6 sulfatase (GALNS). Clinical findings normally include cardiovascular involvement, with moderate mitral e aortic regurgitation and valve thickening (Hendriksz et al., 2013). Heart failure is the most common cause of death amongst patients ( $\mathrm{Ri}$ gante and Segni 2002).

The first record of gene therapy for MPS IV A dates back to 2001, where patients' fibroblasts and other lineage cells were transduced in vitro by retroviral vector containing the GALNS cDNA and efficiently produced the missing enzyme from 5-fold to 50-fold higher than the baseline enzyme activity of normal non-transduced cells (Toietta et al., 2001). Only one paper described the use of gene therapy in vivo, in which MPS IV A mice were treated with AAV vector carrying GALNS cDNA. Twelve weeks after treatment, GALNS activity was about $30 \%$ of wild-type in the heart (Tomatsu et al., 2014).

\section{MPS Type VI}

MPS VI (Maroteaux-Lamy syndrome) is an autosomal recessive disease caused by mutations in the arylsulfatase $B$ ( $A R S B$ ) gene, resulting in reduced or absent enzyme activity of arylsulfatase B (ARSB), responsible for the breakdown of dermatan sulphate. Cardiac disease is frequent in MPS VI patients and is an important cause of morbidity and mortality (Braunlin et al., 2011). Common features are valve stenosis and/or insufficiency, with mitral valve being affected in $96 \%$ of the patients (Valayannopoulos et al., 2010).

Gene therapy for MPS VI is being developed mainly using AAV vectors designed to target the liver, trying to use the organ as a factory that secretes enough enzyme to be taken up by the whole body. Tests were performed in cats 
and rats, and increased ARSB activity and GAG clearance was observed in heart from both animal models after intravenous or intramuscular AAV treatment (Tessitore et al., 2008). However, the intramuscular treatment showed a positive response in visceral organs, probably due to leakage of vector to other tissues, thus transducing other cell types, rather than a cross-correction effect. In addition, it elicited a humoral immune response in rats, resulting in ARSB levels decay. Thereafter, in another study (Cotugno et al., 2010), the same AAV2/8-TBG-hARSB vector, with the liver-specific promoter TBG (Thyroxine Binding Globulin), was administered intravenously in MPS VI rats, newborn and juvenile, concomitant with immunosuppressive drugs (IS) to minimize the possible drawback caused by the immune response previously reported. GAG storage in heart valves was similar in AVV treated and non-treated MPS VI rats whereas it was reduced in AAV+IS group. Nevertheless, results varied considerably and were not reproducible in the cat model, which can be explained by the mixed genetic background of these animal models and differences in the performance of the essays.

Cotugno et al. (2011) used the same AAV2/8-TBGfARSB vector intravenously in 5 and 50-days-old MPS VI cats (newborn and juvenile groups, respectively). Soon after administration of high vector doses $\left(6 \times 10^{13} \mathrm{gc} / \mathrm{kg}\right)$ in 5-days-old kittens, serum ARSB activity levels were 30fold higher than normal, but shortly dropped to normal range due to intense hepatocyte proliferation, resulting in vector dilution since AAV vector is not integrative. On the other hand, same vector doses administered in juvenile group resulted in stable high ARSB activity and maintenance above or within the normal range throughout the follow-up time, suggesting that late gene therapy with AAV2/8 vector may be beneficial for eventual clinical application, since MPS VI patients are not normally diagnosed at birth. In this study, echocardiographic analysis was performed in 9-12 month-old animals. Untreated cats presented important mitral valve thickening, while treated cats had the condition reduced or normalized (Cotugno et al., 2011).

In mice, AAV2/8-TBG-hARSB was used with intravenous injection in 30 days-old MPS VI mice in comparison to ERT (Ferla et al., 2014). Both treatments showed to be effective in reduction of GAG storage in myocardium and heart valves, although gene therapy provided stable ARSB levels (on average 17\% of normal levels) without the peak-and-drop serum kinetics observed with ERT. On the other hand, since high vector doses may compromise liver function, association between gene therapy and ERT was tested using a single IV administration of low dose AAV2/8 $\left(<2 \times 10^{12} \mathrm{gc} / \mathrm{kg}\right)$ and monthly enzyme infusions, resulting in increased ARSB activity and GAGs reduction in heart valves and myocardium compared to ERT alone (Alliegro et al., 2016).
Finally, the vector AAV2/8-TBG-hARSB seems safe and effective up to 180 post-administration in MPS VI mice, as observed in a safety study (Ferla et al., 2017), showing the feasibility of a possible translation of the therapy to the clinic.

Retroviral vector was also tested in MPS VI animal models. MPS VI kittens were treated with RV vector hAAT-fARSB-WPRE within 4 days after birth. As a result, GAG deposition reduced drastically in all tissues analysed from treated cats compared to untreated. Conversely, serum ARSB activity in RV group ranged an average of 13-fold compared to homozygous normal cats and 60-fold compared to the untreated MPS VI group. However, the enzyme activity in visceral organs including heart and aorta were $9-85 \%$ of the values in unaffected cats, demonstrating that the enzyme is not being taken up to cells efficiently even though there are supraphysiologic levels on the bloodstream. Untreated MPS VI cats eventually developed aortic dilatation at the sinus of Valsalva and at the sinotubular junction, aortic valve regurgitation, thickened aortic valve leaflets and thickening of the mitral valve. These conditions were not present in normal cats and all but thickening of mitral valve were significantly reduced in RV treated animals. Hence, neonatal gene therapy seems to prevent aortic dilatation and aortic valve thickening, although this does not indicate resolution of cardiac disease (Ponder et al., 2012).

\section{MPS Type VII}

Mucopolysaccharidosis type VII, or Sly syndrome, is caused by $\beta$-glucoronidase (GUSB) deficiency, resulting in lysosomal build-up of chondroitin, dermatan and heparan sulfate. Cardiac symptoms include coronary artery disease, aortic dilation, thickened and stenotic aortic valve leaflets, intimal thickening of the aorta and left ventricular hypertrophy (Braunlin et al., 2011; Gniadek et al., 2015).

Since the late 1990s, several studies have been published analysing the effect of gene therapy on the cardiovascular system in MPS VII animal models. Daly et al. (1999) injected intravenously an AAV vector with human GUSB cDNA in newborn MPS VII mice resulting in stable GUSB expression, higher than normal, for up to 16 weeks in the heart. Contrarily, the RV vector hAAT-GUSB with pre-treatment of AV-CMV-HGF (HGF - Hepatocyte Growth Factor) - which induces transient hepatocyte replication thus allowing the RV vector to transduce the dividing cells - increased GUSB activity in heart only slightly (about 5\%) and lysosomal storage did not improve (Gao et al., 2000).

The retroviral vector hAAT-cGUSB-WPRE had better outcomes, as presented in few studies using murine and canine MPS VII animal models. Three newborn MPS VII dogs were treated intravenously (Ponder et al., 2002), none of which presented aortic valve insufficiency or mitral valve thickening at 8-9 months, common features of agematched MPS VII dogs, and only one had mild mitral re- 
gurgitation. Subsequently, Sleeper et al.(2004) published a neonatal treatment of dogs with the RV vector hAAT-cGUSB-WPRE, which resulted in improvement in echocardiographic analyses - tricuspid, aortic and pulmonary valves thickness were normal in all treated dogs, none had murmurs and aortic diameter was within normal limits. Two dogs presented insignificant mitral regurgitation at 9 to 11 months; and at 2 years of age, one had minimal mitral regurgitation, but the same happened to 3 out of the 7 normal dogs analysed. GUSB activity in the aorta and myocardium was around $17 \%$ and $19 \%$ of normal, respectively, and GAG content were reduced to $178 \%$ of normal in both aorta and myocardium.

Histologically, the aorta from RV-treated dogs had fusiform myocytes with minimal hypertrophy and vacuolated cytoplasm, in contrast to the rounded, severely hypertrophic and vacuolated muscle cells found in the aortas of untreated dogs. Also, untreated MPS VII dogs had important nodular thickening of the mitral valve, while only mild thickening was seen in the treated group. Although the treatment did not clear GAG storage completely, these results have shown that neonatal intravenous RV gene therapy can ameliorate cardiovascular abnormalities in dogs with MPS VII, with no adverse effects.

Additionally, MPS I and VII dogs were treated with the RV vector hAAT-cIDUA-WPRE and hAAT-cGUSBWPRE, respectively, at 2 to 3 days after birth (Metcalf et al., 2010). All MPS VII treated dogs had stable high serum GUSB activity throughout the evaluation period, which means up to 8 years for some dogs, albeit GUSB activity in aorta was relatively low, reflecting the poor diffusion of the enzyme in this structure. The aorta appeared normal in a 6 month-old RV-treated MPS VII dog with high enzyme activity in serum, however in an 8 year-old treated dog the aorta was dilated and the aortic valve was thickened, with reduced range of motion. The first dog had $148 \%$ of normal enzyme activity and the second had $52 \%$, which may contribute for the difference in the outcome. Summarizing, aortas from treated dogs appeared normal in the first 5 years after gene therapy, statistically better than untreated group, but became dilated thereafter, at 8 years of age. Since GUSB expression remained stable, the treatment with gene therapy delayed the aortic pathology but did not prevent it.

Mitral valve disease progression in MPS VII dogs was also evaluated by the same group (Bigg et al., 2013). The authors suggested that mitral regurgitation occurs due to reduced content of collagen and its abnormal structure in the mitral valve, as evaluated by Masson's trichrome and Picrosirius-red staining, respectively. Normal and treated dogs had higher collagen content than MPS VII animals, although in the treated group it was slightly less than normal. Regarding collagen structure, RV gene therapy improved the integrity of the fibers to $45 \%$ of normal and 5 -fold the value in untreated MPS VII dogs at 6 months of age. Biochemical analysis showed almost complete GAGs clear- ance and reduced protease activity such as cysteine cathepsins in RV treated samples.

In mice, GUSB activity was statistically higher in the hearts of mice treated with hAAT-cGUSB-WPRE than in the untreated group and GAG storage was cleared in heart valves and aorta of RV groups with high GUSB circulating levels (Xu et al., 2002). In another study with the same protocol, GUSB activity in aortas from treated animals was statistically higher, with 5-fold the value of normal mice and 325-fold higher than the untreated group. GAG levels were 111-fold normal in MPS VII mice aortas and significantly reduced to 5\% in RV treated mice. Although biochemical parameters were improved, aortic diameter in treated animals was about $155 \%$ of normal at 10 months of age, thus aortic disease still developed and progressed, giving another evidence that this gene therapy protocol was not fully effective in aortic abnormalities (Baldo et al., 2011).

Other studies were conducted without performing functional analysis of heart and using different approaches. Serotype 2 AAV vector expressing human GUSB were administered intrahepatically in MPS VII adult mice, resulting in GUSB activity at 15\% of normal (Sferra et al., 2004). Besides AAV vector, the lentiviral vector derived from the Human Immunodeficiency Vector pHIV-1EF1 $\alpha$-GUSB $(1 \mathrm{EF} 1 \alpha$ - Eukaryotic Translation Elongation Factor $1 \alpha 1)$ was tested, administered intravenously in newborn pups 2 days after birth. Mice from two different strains were used, GUS $^{\mathrm{tm}(\mathrm{L} 175) \text { Sly }}$ and GUS ${ }^{\mathrm{mps} / \mathrm{mps}}$, representing the attenuated and severe form of the disease, respectively. Transduction of heart myocytes were more efficient in GUS ${ }^{\operatorname{tm}(\mathrm{L} 175) \text { Sly }}$ animals, as was the GUSB activity, reaching about $60 \%$ of normal in the organ. GAG storage reduced, but was still present in animals from both strains (Derrick-Roberts et al., 2014). When treating older mice, results were more modest (Derrick-Roberts et al., 2016).

\section{Sphingolipidoses}

\section{Fabry Disease}

Fabry Disease is an X-linked disorder caused by deficiency of the lysosomal hydrolase $\alpha$-galactosidase A ( $\alpha$ GalA) with consequent accumulation of globotriaosylceramide (Gb3) within lysosomes. Cardiac symptoms are very common in both men and women with the classic form or the cardiac variant. Moreover, these are main causes of morbidity and mortality. The symptoms include: cardiac hypertrophy associated with depressed contractility and diastolic filling impairment, coronary insufficiency, atrioventricular conduction disturbances, arrhythmias and valvular involvement (Linhart and Elliott, 2007)

The initial reports of gene therapy in Fabry used adenoviral vectors (Ziegler et al., 1999) (Table 4). The $\mathrm{AV}-\mathrm{CMV}-\alpha-\mathrm{GalA}$ vector was administered via tail vein in the mouse model. Enzyme activity and Gb3 levels were 


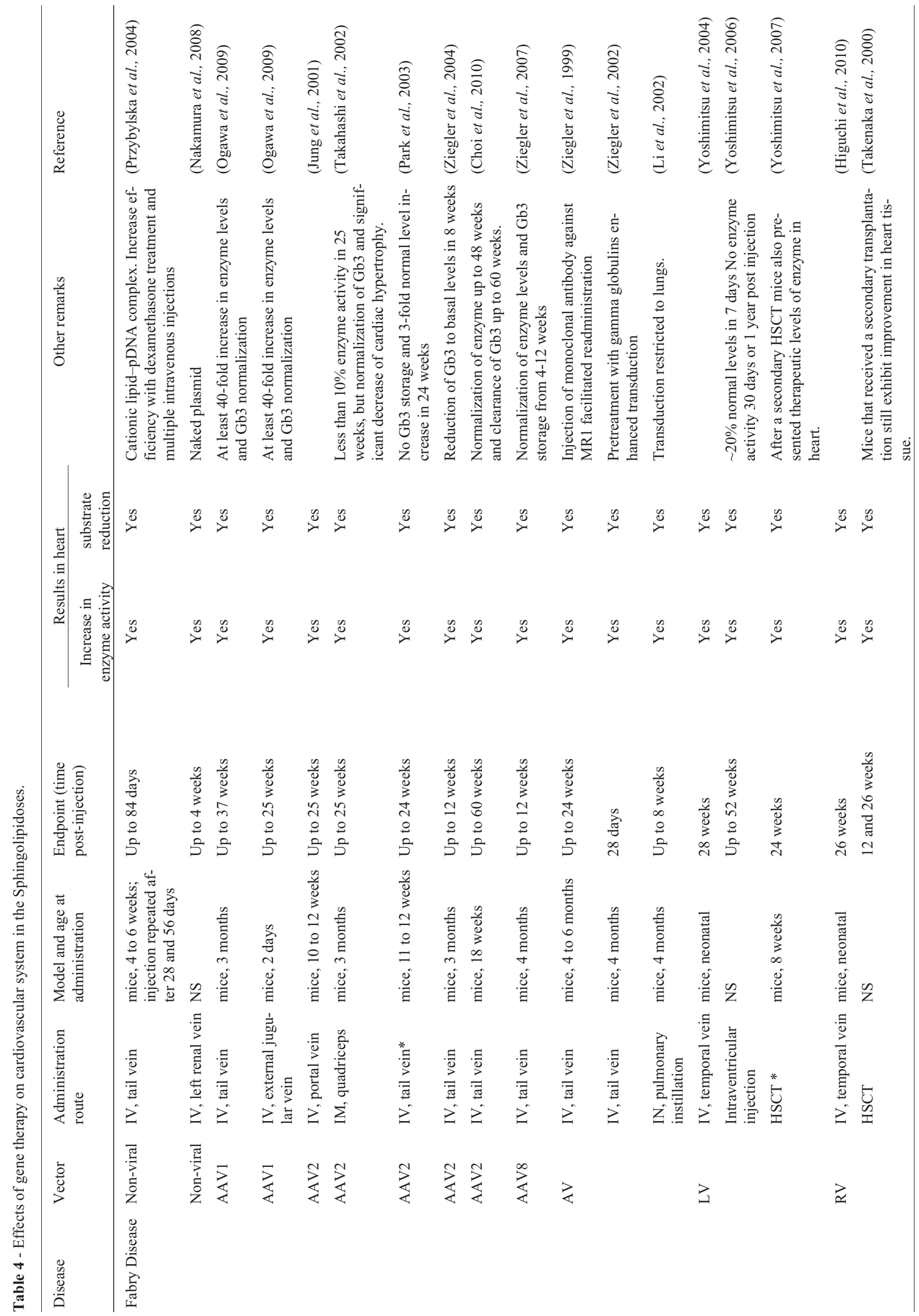




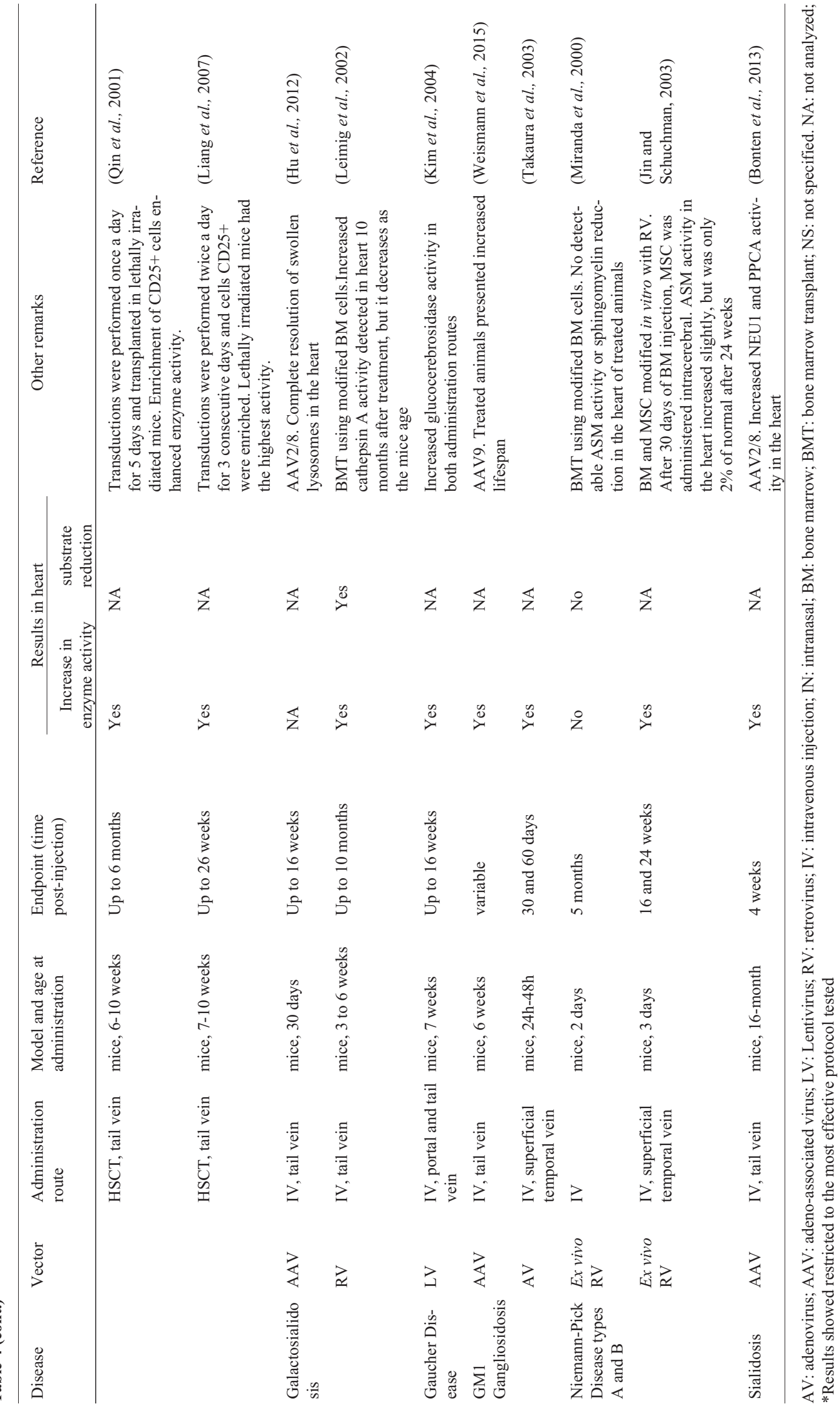


normalized in several tissues, including heart. However, expression declined rapidly and there was reaccumulation of substrate after 6 months. Immunosuppression with a monoclonal antibody against CD40 ligand enhanced outcome of vector readministration. The same group also demonstrated that both depletion of Kupfer cells or pretreatment with gamma globulins could significantly increase AV transduction (Ziegler et al., 2002) and that pulmonary instillation was an effective administration method (Li et al., 2002).

Adeno-associated vectors were the most frequently used vector in reports that evaluated cardiac tissue. Jung et al. (2001) detected increased enzyme activity and reduced substrate accumulation in the heart of Fabry mice 25 weeks after injection of an AAV2 vector. Administration of another AAV2 vector in the quadriceps increased enzymatic activity for 30 weeks without development of antibodies (Takahashi et al., 2002). Echocardiography showed that cardiac hypertrophy was significantly reduced. Although the authors detected clearance of cardiac Gb3, wall thickness was not normalized. Since animals were 3-month-old when injected, it is possible that irreversible structural changes were already established and the treatment cannot revert them. This type of vector proved to be very effective, since other authors also reported increased enzymatic activity to at least normal levels and/or complete clearance of $\mathrm{Gb} 3$ deposits for up to 60 weeks with the use of intravenously injected AAV1(Ogawa et al., 2009), AAV2 (Park et al., 2003; Ziegler et al., 2004; Choi et al., 2010), or AAV8 (Ziegler et al., 2007) vectors.

Lentiviral vectors were injected in the temporal vein of neonatal Fabry mice (Yoshimitsu et al., 2004; Higuchi et al., 2010). After 26 to 28 weeks, both studies reported reduction in $\mathrm{Gb} 3$ and increase $\alpha$-GalA activity in the heart. The latter study further demonstrated that fusion of $\alpha$-GalA with the protein transduction domain (PTD) from HIV transactivator of transcription (Tat) protein could enhance the $\mathrm{Gb} 3$ reduction. Direct heart intraventricular injection of LV was also shown to reduce disease burden in the cardiac tissue for short-term period (Yoshimitsu et al., 2006).

The combined use of gene therapy and HSCT was also evaluated. Takenaka et al. (2000) used $\alpha$-Gal-deficient HSC from 10-week-old donor mice that were transduced four times with a retrovirus encoding $\alpha$-GalA. Subsequently, cells were transplanted into sublethally and lethally irradiated $\alpha$-GalA-deficient mice. After 26 weeks, increased $\alpha$-GalA activity and decreased Gb3 storage were observed in the heart and other organs, particularly in the group lethally irradiated. Although in a smaller scale, these results were observed even after a secondary transplant was performed (Takenaka et al., 2000). Qin et al. (2001) used a bicistronic retroviral vector that expressed $\alpha$-GalA and a selectable marker (CD25 - Interleukin 2 Receptor $\alpha$ ). They harvested HSC from 6- to 10-week-old male Fabry mice and transduced once a day for 5 days. Cells were then sorted by flow cytometry and immunoaffinity enrichment and were injected via tail veins into several groups, including lethally irradiated Fabry mice. Tissue analysis after 6 months indicated near normal $\alpha$-GalA levels in the heart of these animals. Moreover, a second transplantation of cells collected from these primary transplanted mice was performed. From the 5 transplanted mice, 3 showed enzyme levels equal or higher to normal in plasma. No evaluation of GB3 was performed (Qin et al., 2001). Later, the effects of different Reduced-intensity Conditioning Regimens, in addition to pre-selection, were also analysed. Liang et al. (2007) described that both limb irradiation with lethal dose of X-ray and treatment with Fludarabine and Cyclophosphamide increased enzymatic activity after transduction with the same RV as the previous study. However, it was a modest increase. Only mice lethally irradiated presented near normal levels of enzyme activity in the heart with clearance of Gb3. In the same year, another group used a LV to transduce bone marrow mononuclear cells and transplant into Fabry mice. Treatment was effective and resulted in supraphysiological levels of enzyme and total clearance of substrate in the heart and other tissues. After a secondary transplant, enzymatic levels were still elevated in several tissues when compared to untreated mice (Yoshimitsu et al., 2007).

Finally, the use of non-viral vectors as naked plasmid and cationic lipid-pDNA complex was also reported (Przybylska et al., 2004; Nakamura et al., 2008). Although these are safer options, these vectors were not as effective as viral vectors and were unable to normalize the disease in the mouse model.

\section{Galactosialidosis}

Galactosialidosis (GS) is an autosomal recessive disease caused by mutations in the Cathepsin A gene (CTSA) that encodes the protective protein/cathepsin A (PPCA). Defective PPCA leads to secondary combined deficiency of $\beta$-galactosidase and neuraminidase, resulting in sialyloligosaccharides and glycopeptides accumulation. Patients present typical lysosomal disorder manifestations, such as coarse facies and skeletal deformities (OkamuraOho et al., 1994). Myocardial tissue is thickened and vacuolated and cardiovascular disease may occur, with mitral and aortic valve thickening leading to valve insufficiency (Bursi et al., 2003) and left ventricular dilatation (Okamura-Oho et al., 1994).

Initially, gene therapy studies focused on developing overexpressing PCAA transgenic mice to use as HSC donors to transplant PCAA-KO mice, which resulted in mild improvement in phenotype (Hahn et al., 1998; Zhou et al., 1995). Later on, an ex vivo gene therapy protocol was tested using RV MSCV-PPCA (MSCV - Murine Stem Cell Virus) modified PCAA-KO hematopoietic progenitor cells to transplant PCAA-KO mice. Although the number of PPCA 
expressing cells varied between treated mice, systemic correction was observed in all MSCV-PPCA transplanted animals. In heart homogenate, cathepsin A activity was detected at higher levels than in untreated group for as long as 10 months (Leimig et al., 2002).

The latest published study using gene therapy was using the vector AAV2/8-LP1-PPCA (LP1 - Liver Specific Promoter) to treat a cohort of sixty 30-day-old PCAA-KO mice, intravenously and with three vector doses. In addition to improved overall appearance and rescue of fertility, histological heart sections showed complete resolution of swollen lysosomes, as seen in other tissues $(\mathrm{Hu}$ et al., 2012).

\section{Gaucher Disease}

Gaucher disease (GD) is the most common LSD, with an estimated worldwide incidence of 1:75.000 (Huang et al., 2015). It is caused by deficiency of the enzyme glucocerebrosidase (GCase) and consequent deposition of the substrate glucocerebroside in liver, spleen and bone. There are three classical forms depending on the severity and onset of symptoms - type I (most common, without CNS involvement), type II (acute neuronopathic form) and type III (chronic neuronopathic form). The latter is characterized by a more attenuated phenotype, with mild neuronopathic features and visceral manifestations, including cardiac symptoms.

Patients with Gaucher disease type III (GD III) generally present widespread calcification of cardiovascular structures, such as ascending aorta, coronary and carotid arteries, and cardiac valves, leading to valvular stenosis, dilated cardiomyopathy and possibly congestive heart failure (Guertl et al., 2000).

Most gene therapy studies for GD were developed in the 1990's, focusing mainly on protocols of in vitro HSC transduction for HSCT. After creation of GD murine models, some studies tried ex or in vivo gene therapy in mice, one of them resulting in increased GCase in the heart (Kim et al., 2004). However, gene therapy for GD was not as successful as it seemed for other LSDs, probably because GCase is not normally secreted unless cells are expressing high levels of the enzyme, requiring very efficient vectors to deliver and induce significant gene expression (Marshall et al., 2002).

\section{GM1 Gangliosidosis}

GM1 gangliosidosis is characterized by accumulation of GM1 gangliosides and related glycoconjugates in lysosomes due to $\beta$-galactosidase ( $\beta$-gal) deficiency. Besides manifestations shared by most LSDs, one third of patients with GM1 gangliosidosis present congestive cardiomyopathy, regardless the classification of the disease (infantile, juvenile and adult) (Guertl et al., 2000; Morrone et al., 2000; Brunetti-Pierri and Scaglia, 2008).
Since cardiac involvement is not experienced by all patients, and neurological involvement is very pronounced, gene therapy protocols developed so far did not focus on heart manifestations but on the CNS. A couple of studies designed to target the CNS described an increase of $\beta$-gal activity in heart and other visceral tissues, using either AV vector (Takaura et al., 2003) or AAV (Weismann et al., 2015) when treating GM1 gangliosidosis mice.

\section{Niemann-Pick Disease types A and B}

Niemann-Pick disease (NPD) is caused by storage of sphingomyelin within lysosomes mainly of monocytes and macrophages. Niemann-Pick types A and B are associated with mutations in the Sphingomyelin Phosphodiesterase 1 gene (SMPD1) and type $\mathrm{C}$ is caused by mutations in the Intracellular Cholesterol Transporter genes (NPC1 or $N P C 2$ ), thus presenting different clinical features. Both types A and B are a result of acid sphingomyelinase (ASM) deficiency, though NPD-A has neuronal involvement ,while NPD-B is only visceral (Schuchman and Wasserstein, 2015).

Early cardiovascular disease may occur in some patients with NPD-A and NPD-B, presenting valvar or coronary artery disease, which in turn is probably caused by the abnormal atherogenic lipid profile found in most patients. The mechanisms regarding valvar disease are still unknown (McGovern et al., 2013).

The first paper describing gene therapy for NPD used 2-days-old ASM-KO mice injected with bone marrow cells previously modified with retroviral vector containing ASM (acid sphingomyelinase). ASM levels and sphingomyelin storage in the heart of treated animals were not statistically different than those found in the untreated mice. In other organs, the results were slightly better, suggesting improvement of disease manifestations. However, all transplanted mice eventually developed ataxia and died earlier than normal mice, which highlighted the need of further studies (Miranda et al., 2000). Subsequently, a similar approach using two transplants - one with modified bone marrow cells intravenously at day 3 after birth and another with modified mesenchymal stem cells intracerebrally at day 30 - achieved improvement of neurological features, and ASM activity initially increased in the heart, though it decreased to only $2 \%$ of normal after 24 weeks (Jin and Schuchman, 2003). To our knowledge, none of published studies evaluated the efficiency of gene therapy on cardiac disease of NPD.

\section{Sialidosis}

Sialidosis is caused by progressive accumulation of sialylated glycopeptides and oligosaccharides due to neuraminidase 1 (NEU1) deficiency, also known as sialidase. General clinical manifestations include visceromegaly, coarse facies, dysostosis multiplex and mental retardation. Patients may also present cardiac anomalies, including val- 
ve disease and increased ventricular wall thickness (Senocak et al., 1994). Currently, no treatment is available.

Genetic transference of NEU cDNA to patients' fibroblasts has been tested to induce transient expression of the missing enzyme. NEU levels in fibroblasts were restored to normal range and increased further 10-fold when co-transfection with cathepsin A cDNA (PPCA, a chaperone required for lysosomal routing) was performed (Igdoura et al., 1998); abnormal sialylglycoprotein deposits were reduced to normal levels as well (Oheda et al., 2006). In vivo gene therapy using AAV2/8 vector to deliver the PPCA cDNA resulted in indirect increase in NEU activity from its residual levels, including in the heart. Further studies should be performed in order to better understand the disease mechanisms and more efficient approaches of therapy.

\section{Conclusion and final considerations}

Gene therapy is being tested along the last three decades for many diseases, and it seems very promising to

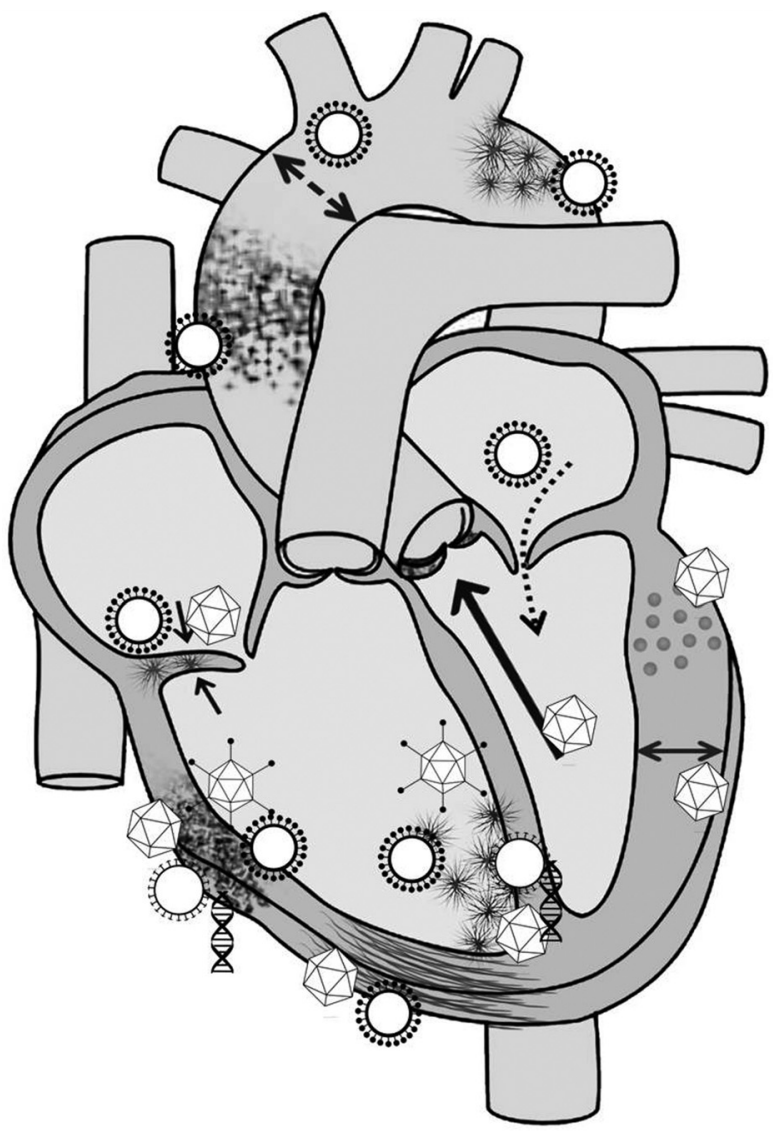

Nonviral vectors treat LSDs. Since cardiovascular disease is an important feature of many of them - normally being one of the main causes of mortality among patients - it is important to evaluate how efficient this therapy is on the cardiovascular system and how it can impact on the patient's life.

Many gene therapy protocols have already been tested and, so far, they showed better results when performed in young and in immunodeficient/pre-conditioned animals. Intravenous injection is the most used route of administration because it is the one that distributes the vector more homogenously. Retrovirus and adeno-associated virus are the most used vectors and have not yet produced serious adverse effects in these animal models, being efficient and apparently safe.

The heart seems to be much beneficiated from most of gene therapy protocols, ameliorating or normalizing many of analysed parameters (Figure 1), such as wall thickness, electric conductance and heart rate. On the other hand, heart valves and aorta do not respond so well, probably due to poor and/or uneven vascularization, even when there are

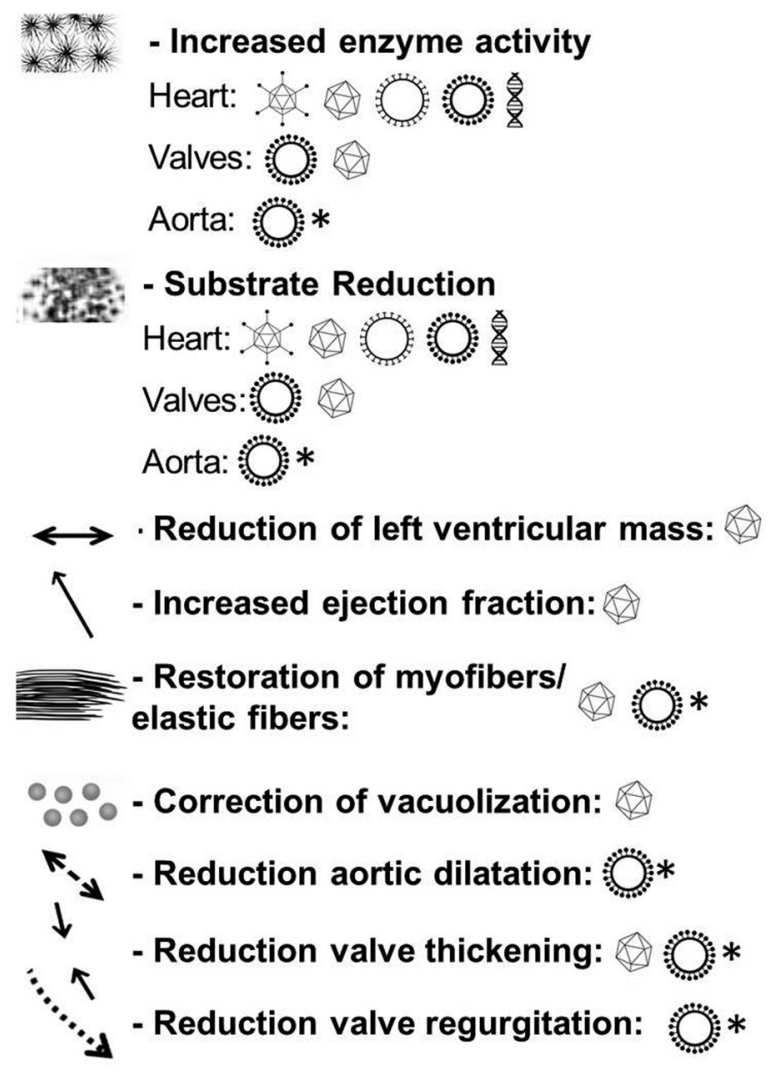

- Increased enzyme activity

Heart: $\otimes 2$

Valves:

Aorta:

- Substrate Reduction

Heart: $\otimes$

Valves:O

Aorta: $*$

$\longleftrightarrow$ - Reduction of left ventricular mass:

- Increased ejection fraction:

Restoration of myofibers/ elastic fibers:

00 - Correction of vacuolization:

s. - Reduction aortic dilatation:

- Reduction valve regurgitation:

Adeno associated virus Adenovirus

Figure 1 - Cardiovascular response to gene therapy depending on vector used, according to studies for lysosomal storage diseases. Schematic representation of the heart and the aorta showing the most prominent cardiovascular manifestations of lysosomal storage diseases (right) with the results obtained from in vivo gene therapy using different vectors (bottom). Retroviral and adeno-associated viral vectors resulted in better outcome for many aspects of the disease (although most studies using other vectors did not analyse thoroughly the effect of gene therapy on cardiovascular manifestations and there is no data available). Valves and aorta are most difficult to treat, as most vectors do not reach these structures as easily as the myocardium. Some features were only restored or prevented when treated in the first days of life (represented by * next to the vector symbol). 
supraphysiologic levels of missing enzyme in the bloodstream. Aortic dilatation, valve thickening, valve regurgitation and valve insufficiency were delayed in most treated animals with MPS, but they still developed these conditions eventually. For Fabry and Pompe diseases, a similar outcome was observed - all treated mice had improvement in cardiac tissues, but the overall pathology was only partially corrected. For other diseases cited in this revierw, reduction of substrate and increase in enzyme activity was achieved after gene therapy, but this does not indicate cardiac disease resolution due to lack of more specific functional analysis.

\section{Future directions}

There are numerous studies using gene therapy so far, and this approach seems very promising, although more tests should still be performed, perhaps with combined treatments. The use of adjuvant drugs to modulate immune response or to increase enzyme uptake could be helpful, since only increasing serum levels does not seem suficient to have a complete correction of the phenotype.

Nanotechnology-based carriers designed specifically to target valve and aortic tissues, for example, could be a great adjuvant to current limited vectors. Possibly there will not be one perfect vector to fit all demands in an organism affected by a multisystemic disease, but an association of strategic vectors and adjuvant drugs could be the final solution.

Nonetheless, even if not completely corrective yet, stabilizing the disease or delaying the progression of important cardiovascular pathologies could make a big difference for the patient and thus should be continuously pursued.

\section{Acknowledgments}

We thank CNPq and Fipe-HCPA for financial support.

\section{Conflict of interest}

The authors declare absence of conflicts of interest.

\section{Author contributions}

EP and GP collected the data and wrote the manuscript; RG, UM and GB conceived the study and revised the manuscript. All authors read and approved the submitted version of the manuscript.

\section{References}

Alfranca A, Campanero MR and Redondo JM (2018) New methods for disease modeling using lentiviral vectors. Trends Mol Med 24:825-837.

Alliegro M, Ferla R, Nusco E, De Leonibus C, Settembre C and Auricchio A (2016) Low-dose gene therapy reduces the fre- quency of enzyme replacement therapy in a mouse model of lysosomal storage disease. Mol Ther 24:2054-2063.

Aronovich EL, Bell JB, Khan SA, Belur LR, Gunther R, Koniar B, Schachern PA, Parker JB, Carlson CS, Whitley CB et al. (2009) Systemic correction of storage disease in MPS I NOD/SCID mice using the sleeping beauty transposon system. Mol Ther 17:1136-1144.

Baldo G, Wu S, Howe RA, Ramamoothy M, Knutsen RH, Fang J, Mecham RP, Liu Y, Wu X, Atkinson JP and Ponder KP (2011) Pathogenesis of aortic dilatation in mucopolysaccharidosis VII mice may involve complement activation. Mol Genet Metab 104:608-619.

Baldo G, Mayer FQ, Martinelli B, Meyer FS, Burin M, Meurer L, Tavares AM, Giugliani R and Matte U (2012) Intraperitoneal implant of recombinant encapsulated cells overexpressing alpha-L-iduronidase partially corrects visceral pathology in mucopolysaccharidosis type I mice. Cytotherapy 14:860-867.

Bigg PW, Sleeper MM, O’Donnell PA, Liu Y, Wu S, Casal ML, Haskins ME and Ponder KP (2013) The effect of neonatal gene therapy with a gamma retroviral vector on cardiac valve disease in mucopolysaccharidosis VII dogs after a decade. Mol Genet Metab 110:311-318.

Bonten EJ, Yogalingam G, Hu H, Gomero E, van de Vlekkert D and d'Azzo A (2013) Chaperone-mediated gene therapy with recombinant AAV-PPCA in a new mouse model of type I sialidosis. Biochim Biophys Acta 1832:1784-1792.

Boustany RM (2013) Lysosomal storage diseases - the horizon expands. Nat Rev Neurol 9:583-598.

Brands MM, Frohn-Mulder IM, Hagemans ML, Hop WC, Oussoren E, Helbing WA and van der Ploeg AT (2013) Mucopolysaccharidosis: Cardiologic features and effects of enzyme-replacement therapy in 24 children with MPS I, II and VI. J Inherit Metab Dis 36:227-234.

Braun SE, Aronovich EL, Anderson RA, Crotty PL, McIvor RS and Whitley CB (1993) Metabolic correction and crosscorrection of mucopolysaccharidosis type II (Hunter syndrome) by retroviral-mediated gene transfer and expression of human iduronate-2-sulfatase. Proc Natl Acad Sci U S A 90:11830-11834.

Braun SE, Pan D, Aronovich EL, Jonsson JJ, McIvor RS and Whitley CB (1996) Preclinical studies of lymphocyte gene therapy for mild Hunter syndrome (mucopolysaccharidosis type II). Hum Gene Ther 7:283-290.

Braunlin E, Mackey-Bojack S, Panoskaltsis-Mortari A, Berry JM, McElmurry RT, Riddle M, Sun LY, Clarke LA, Tolar J and Blazar BR (2006) Cardiac functional and histopathologic findings in humans and mice with mucopolysaccharidosis type I: Implications for assessment of therapeutic interventions in hurler syndrome. Pediatr Res 59:27-32.

Braunlin EA, Harmatz PR, Scarpa M, Furlanetto B, Kampmann C, Loehr JP, Ponder KP, Roberts WC, Rosenfeld HM and Giugliani R (2011) Cardiac disease in patients with mucopolysaccharidosis: presentation, diagnosis and management. J Inher Metab Dis 34:1183-1197.

Brunetti-Pierri N and Scaglia F (2008) GM1 gangliosidosis: Review of clinical, molecular, and therapeutic aspects. Mol Genet Metab 94:391-396.

Bursi F, Osranek M, Seward JB and O'Leary PW (2003) Mitral and aortic valve thickening associated with galactosia- 
lidosis: echocardiographic features of a lysosomal storage disease. Echocardiography 20:605-606.

Cardone M, Polito VA, Pepe S, Mann L, D’Azzo A, Auricchio A, Ballabio A and Cosma MP (2006) Correction of Hunter syndrome in the MPSII mouse model by AAV2/8-mediated gene delivery. Hum Mol Genet 15:1225-1236.

Cathey SS, Leroy JG, Wood T, Eaves K, Simensen RJ, Kudo M, Stevenson RE and Friez MJ (2010) Phenotype and genotype in mucolipidoses II and III alpha/beta: A study of 61 probands. J Med Genet 47:38-48.

Cheng Z and Fang Q (2012) Danon disease: focusing on heart. J Hum Genet 57:407-410.

Choi JO, Lee MH, Park HY and Jung SC (2010) Characterization of Fabry mice treated with recombinant adeno-associated virus 2/8-mediated gene transfer. J Biomed Sci 17:26.

Clarke LA and Hollak CE (2015) The clinical spectrum and pathophysiology of skeletal complications in lysosomal storage disorders. Best Pract Res Clin Endocrinol Metab 29:219-235.

Collins M and Thrasher A (2015) Gene therapy: progress and predictions. Proc Biol Sci 282:20143003.

Cotrim AP and Baum BJ (2008) Gene therapy: Some history, applications, problems, and prospects. Toxicol Pathol 36:97103.

Cotugno G, Tessitore A, Capalbo A, Annunziata P, Strisciuglio C, Faella A, Aurilio M, Di Tommaso M, Russo F, Mancini A et al. (2010) Different serum enzyme levels are required to rescue the various systemic features of the mucopolysaccharidoses. Hum Gene Ther 21:555-569.

Cotugno G, Annunziata P, Tessitore A, O’Malley T, Capalbo A, Faella A, Bartolomeo R, O'Donnell P, Wang P, Russo F et al. (2011) Long-term amelioration of feline Mucopolysaccharidosis VI after AAV-mediated liver gene transfer. Mol Ther 19:461-469.

Cresawn KO, Fraites TJ, Wasserfall C, Atkinson M, Lewis M, Porvasnik S, Liu C, Mah C and Byrne BJ (2005) Impact of humoral immune response on distribution and efficacy of recombinant adeno-associated virus-derived acid alpha-glucosidase in a model of glycogen storage disease type II. Hum Gene Ther 16:68-80.

Daly TM, Vogler C, Levy B, Haskins ME and Sands MS (1999) Neonatal gene transfer leads to widespread correction of pathology in a murine model of lysosomal storage disease. Proc Natl Acad Sci U S A 96:2296-2300.

Derrick-Roberts AL, Pyragius CE, Kaidonis XM, Jackson MR, Anson DS and Byers S (2014) Lentiviral-mediated gene therapy results in sustained expression of beta-glucuronidase for up to 12 months in the gus(mps/mps) and up to 18 months in the gus(tm(L175F)Sly) mouse models of mucopolysaccharidosis type VII. Hum Gene Ther 25:798-810.

Derrick-Roberts AL, Panir K, Pyragius CE, Zarrinkalam KH, Atkins GJ and Byers S (2016) Reversal of established bone pathology in MPS VII mice following lentiviral-mediated gene therapy. Mole Genet Metab 119:249-257.

Di Domenico C, Villani GR, Di Napoli D, Reyero EG, Lombardo A, Naldini L and Di Natale P (2005) Gene therapy for a mucopolysaccharidosis type I murine model with lentiviral-IDUA vector. Hum Gene Ther 16:81-90.

Di Francesco C, Cracco C, Tomanin R, Picci L, Ventura L, Zacchello E, Di Natale P, Anson DS, Hopwood JJ, Graham FL and Scarpa M (1997) In vitro correction of iduronate- 2-sulfatase deficiency by adenovirus-mediated gene transfer. Gene Ther 4:442-448.

Ding EY, Hodges BL, Hu H, McVie-Wylie AJ, Serra D, Migone FK, Pressley D, Chen YT and Amalfitano A (2001) Long-term efficacy after [E1-, polymerase-] adenovirusmediated transfer of human acid-alpha-glucosidase gene into glycogen storage disease type II knockout mice. Hum Gene Ther 12:955-965.

Doerfler PA, Todd AG, Clement N, Falk DJ, Nayak S, Herzog RW and Byrne BJ (2016) Copackaged AAV9 vectors promote simultaneous immune tolerance and phenotypic correction of Pompe disease. Hum Gene Ther 27:43-59.

Douillard-Guilloux G, Richard E, Batista L and Caillaud C (2009) Partial phenotypic correction and immune tolerance induction to enzyme replacement therapy after hematopoietic stem cell gene transfer of alpha-glucosidase in Pompe disease. J Gene Med 11:279-287.

Falk DJ, Mah CS, Soustek MS, Lee KZ, Elmallah MK, Cloutier DA, Fuller DD and Byrne BJ (2013) Intrapleural administration of AAV9 improves neural and cardiorespiratory function in Pompe disease. Mol Ther 21:1661-1667.

Falk DJ, Soustek MS, Todd AG, Mah CS, Cloutier DA, Kelley JS, Clement N, Fuller DD and Byrne BJ (2015) Comparative impact of AAV and enzyme replacement therapy on respiratory and cardiac function in adult Pompe mice. Mol Ther Methods Clin Dev 2:15007.

Ferla R, Claudiani P, Cotugno G, Saccone P, De Leonibus E and Auricchio A (2014) Similar therapeutic efficacy between a single administration of gene therapy and multiple administrations of recombinant enzyme in a mouse model of lysosomal storage disease. Hum Gene Ther 25:609-618.

Ferla R, Alliegro M, Marteau JB, Dell'Anno M, Nusco E, Pouillot S, Galimberti S, Valsecchi MG, Zuliani V and Auricchio A (2017) Non-clinical safety and efficacy of an AAV2/8 vector administered intravenously for treatment of Mucopolysaccharidosis Type VI. Mol Ther Methods Clin Dev 6:143-158.

Fraites Jr TJ, Schleissing MR, Shanely RA, Walter GA, Cloutier DA, Zolotukhin I, Pauly DF, Raben N, Plotz PH, Powers SK et al. (2002) Correction of the enzymatic and functional deficits in a model of Pompe disease using adeno-associated virus vectors. Mol Ther 5:571-578.

Franco LM, Sun B, Yang X, Bird A, Zhang H, Schneider A, Brown T, Young SP, Clay TM, Amalfitano A et al. (2005) Evasion of immune responses to introduced human acid alpha-glucosidase by liver-restricted expression in glycogen storage disease type II. Mol Ther 12:876-884.

Friso A, Tomanin R, Zanetti A, Mennuni C, Calvaruso F, La Monica N, Marin O, Zacchello F and Scarpa M (2008) Gene therapy of Hunter syndrome: Evaluation of the efficiency of muscle electro gene transfer for the production and release of recombinant iduronate-2-sulfatase (IDS). Biochim Biophys Acta 1782:574-580.

Gao C, Sands MS, Haskins ME and Ponder KP (2000) Delivery of a retroviral vector expressing human beta-glucuronidase to the liver and spleen decreases lysosomal storage in mucopolysaccharidosis VII mice. Mol Ther 2:233-244.

Gniadek TJ, Singer N, Barker NJ, Spevak PJ, Crain BJ, Valle D and Halushka MK (2015) Cardiovascular pathologies in mucopolysaccharidosis type VII (Sly Syndrome). Cardiovasc Pathol 24:322-326. 
Guertl B, Noehammer C and Hoefler G (2000) Metabolic cardiomyopathies. Int J Exp Pathol 81:349-372.

Hahn CN, del Pilar Martin M, Zhou XY, Mann LW and d'Azzo A (1998) Correction of murine galactosialidosis by bone marrow-derived macrophages overexpressing human protective protein/cathepsin A under control of the colony-stimulating factor-1 receptor promoter. Proc Natl Acad Sci U S A 95:14880-14885.

Han SO, Li S, Brooks ED, Masat E, Leborgne C, Banugaria S, Bird A, Mingozzi F, Waldmann H and Koeberl D (2015) Enhanced efficacy from gene therapy in Pompe disease using coreceptor blockade. Hum Gene Ther 26:26-35.

Han SO, Li S and Koeberl DD (2016) Salmeterol enhances the cardiac response to gene therapy in Pompe disease. Mol Genet Metab 118:35-40.

Han SO, Ronzitti G, Arnson B, Leborgne C, Li S, Mingozzi F and Koeberl D (2017) Low-dose liver-targeted gene therapy for Pompe disease enhances therapeutic efficacy of ERT via immune tolerance induction. Mol Ther Methods Clin Dev 4:126-136.

Hartung SD, Frandsen JL, Pan D, Koniar BL, Graupman P, Gunther R, Low WC, Whitley CB and McIvor RS (2004) Correction of metabolic, craniofacial, and neurologic abnormalities in MPS I mice treated at birth with adeno-associated virus vector transducing the human alpha-L-iduronidase gene. Mol Ther 9:866-875.

Hendriksz CJ, Harmatz P, Beck M, Jones S, Wood T, Lachman R, Gravance CG, Orii T and Tomatsu S (2013) Review of clinical presentation and diagnosis of mucopolysaccharidosis IVA. Mol Genet Metab 110:54-64.

Herati RS, Ma X, Tittiger M, Ohlemiller KK, Kovacs A and Ponder KP (2008) Improved retroviral vector design results in sustained expression after adult gene therapy in mucopolysaccharidosis I mice. J Gene Med 10:972-982.

Hicks J, Wartchow E and Mierau G (2011) Glycogen storage diseases: A brief review and update on clinical features, genetic abnormalities, pathologic features, and treatment. Ultrastruct Pathol 35:183-196.

Higuchi K, Yoshimitsu M, Fan X, Guo X, Rasaiah VI, Yen J, Tei C, Takenaka T and Medin JA (2010) Alpha-galactosidase A-Tat fusion enhances storage reduction in hearts and kidneys of Fabry mice. Mol Med 16:216-221.

Hinderer C, Bell P, Gurda BL, Wang Q, Louboutin JP, Zhu Y, Bagel J, O'Donnell P, Sikora T, Ruane T et al. (2014) Liverdirected gene therapy corrects cardiovascular lesions in feline mucopolysaccharidosis type I. Proc Natl Acad Sci U S A 111:14894-14899.

Hinderer C, Katz N, Louboutin JP, Bell P, Yu H, Nayal M, Kozarsky K, O'Brien WT, Goode T and Wilson JM (2016) Delivery of an adeno-associated virus vector into cerebrospinal fluid attenuates central nervous system disease in Mucopolysaccharidosis Type II mice. Hum Gene Ther 27:906-915.

Hordeaux J, Dubreil L, Robveille C, Deniaud J, Pascal Q, Dequeant B, Pailloux J, Lagalice L, Ledevin M, Babarit C et al. (2017) Long-term neurologic and cardiac correction by intrathecal gene therapy in Pompe disease. Acta Neuropathol Commun 5:66.

$\mathrm{Hu} \mathrm{H}$, Gomero E, Bonten E, Gray JT, Allay J, Wu Y, Wu J, Calabrese C, Nienhuis A and d'Azzo A (2012) Preclinical dose-finding study with a liver-tropic, recombinant AAV-
$2 / 8$ vector in the mouse model of galactosialidosis. Mol Ther 20:267-274

Huang WJ, Zhang X and Chen WW (2015) Gaucher disease: A lysosomal neurodegenerative disorder. Eur Rev Med Pharmacol Sci 19:1219-1226.

Igdoura SA, Gafuik C, Mertineit C, Saberi F, Pshezhetsky AV, Potier M, Trasler JM and Gravel RA (1998) Cloning of the cDNA and gene encoding mouse lysosomal sialidase and correction of sialidase deficiency in human sialidosis and mouse SM/J fibroblasts. Hum Mol Genet 7:115-121.

Jayant RD, Sosa D, Kaushik A, Atluri V, Vashist A, Tomitaka A and Nair M (2016) Current status of non-viral gene therapy for CNS disorders. Expert Opin Drug Deliv 13:1433-1445.

Jin HK and Schuchman EH (2003) Ex vivo gene therapy using bone marrow-derived cells: Combined effects of intracerebral and intravenous transplantation in a mouse model of Niemann-Pick disease. Mol Ther 8:876-885.

Jordan MC, Zheng Y, Ryazantsev S, Rozengurt N, Roos KP and Neufeld EF (2005) Cardiac manifestations in the mouse model of mucopolysaccharidosis I. Mol Genet Metab $86: 233-243$

Jung SC, Han IP, Limaye A, Xu R, Gelderman MP, Zerfas P, Tirumalai K, Murray GJ, During MJ, Brady RO and Qasba P (2001) Adeno-associated viral vector-mediated gene transfer results in long-term enzymatic and functional correction in multiple organs of Fabry mice. Proc Natl Acad Sci U S A 98:2676-2681.

Jung SC, Park ES, Choi EN, Kim CH, Kim SJ and Jin DK (2010) Characterization of a novel mucopolysaccharidosis type II mouse model and recombinant AAV2/8 vector-mediated gene therapy. Mol Cells 30:13-18.

Kiang A, Hartman ZC, Liao S, Xu F, Serra D, Palmer DJ, Ng P and Amalfitano A (2006) Fully deleted adenovirus persistently expressing GAA accomplishes long-term skeletal muscle glycogen correction in tolerant and nontolerant GSD-II mice. Mol Ther 13:127-134.

Kim EY, Hong YB, Lai Z, Kim HJ, Cho YH, Brady RO and Jung SC (2004) Expression and secretion of human glucocerebrosidase mediated by recombinant lentivirus vectors in vitro and in vivo: implications for gene therapy of Gaucher disease. Biochem Biophys Res Commun 318:381390.

Kobayashi H, Carbonaro D, Pepper K, Petersen D, Ge S, Jackson H, Shimada H, Moats R and Kohn DB (2005) Neonatal gene therapy of MPS I mice by intravenous injection of a lentiviral vector. Mol Ther 11:776-789.

Kyosen SO, Iizuka S, Kobayashi H, Kimura T, Fukuda T, Shen J, Shimada Y, Ida H, Eto Y and Ohashi T (2010) Neonatal gene transfer using lentiviral vector for murine Pompe disease: long-term expression and glycogen reduction. Gene Ther 17:521-530.

Laoharawee K, Podetz-Pedersen KM, Nguyen TT, Evenstar LB, Kitto KF, Nan Z, Fairbanks CA, Low WC, Kozarsky KF and McIvor RS (2017) Prevention of neurocognitive deficiency in Mucopolysaccharidosis Type II mice by central nervous system-directed, AAV9-mediated iduronate sulfatase gene transfer. Hum Gene Ther 28:626-638.

Leimig T, Mann L, Martin Mdel P, Bonten E, Persons D, Knowles J, Allay JA, Cunningham J, Nienhuis AW, Smeyne R and d'Azzo A (2002) Functional amelioration of murine galacto- 
sialidosis by genetically modified bone marrow hematopoietic progenitor cells. Blood 99:3169-3178.

Leinekugel P, Michel S, Conzelmann E and Sandhoff K (1992) Quantitative correlation between the residual activity of beta-hexosaminidase A and arylsulfatase A and the severity of the resulting lysosomal storage disease. Hum Genet 88:513-523.

Li C, Ziegler RJ, Cherry M, Lukason M, Desnick RJ, Yew NS and Cheng SH (2002) Adenovirus-transduced lung as a portal for delivering alpha-galactosidase A into systemic circulation for Fabry disease. Mol Ther 5:745-754.

Liang SB, Yoshimitsu M, Poeppl A, Rasaiah VI, Cai J, Fowler DH and Medin JA (2007) Multiple reduced-intensity conditioning regimens facilitate correction of Fabry mice after transplantation of transduced cells. Mol Ther 15:618-627.

Linhart A and Elliott PM (2007) The heart in Anderson-Fabry disease and other lysosomal storage disorders. Heart 93:528535.

Liu Y, Xu L, Hennig AK, Kovacs A, Fu A, Chung S, Lee D, Wang B, Herati RS, Mosinger Ogilvie J, Cai SR and Parker Ponder K (2005) Liver-directed neonatal gene therapy prevents cardiac, bone, ear, and eye disease in mucopolysaccharidosis I mice. Mol Ther 11:35-47.

Lizzi Lagranha V, Zambiasi Martinelli B, Baldo G, Avila Testa G, Giacomet de Carvalho T, Giugliani R and Matte U (2017) Subcutaneous implantation of microencapsulated cells overexpressing alpha-L-iduronidase for mucopolysaccharidosis type I treatment. J Mater Sci Mater Med 28:43.

Ma X, Liu Y, Tittiger M, Hennig A, Kovacs A, Popelka S, Wang B, Herati R, Bigg M and Ponder KP (2007) Improvements in mucopolysaccharidosis I mice after adult retroviral vector-mediated gene therapy with immunomodulation. Mol Ther 15:889-902.

Mah C, Cresawn KO, Fraites TJ, Pacak CA, Lewis MA, Zolotukhin I and Byrne BJ (2005) Sustained correction of glycogen storage disease type II using adeno-associated virus serotype 1 vectors. Gene Ther 12:1405-1409.

Mah C, Pacak CA, Cresawn KO, Deruisseau LR, Germain S, Lewis MA, Cloutier DA, Fuller DD and Byrne BJ (2007) Physiological correction of Pompe disease by systemic delivery of adeno-associated virus serotype 1 vectors. Mol Ther 15:501-507.

Marshall J, McEachern KA, Kyros JA, Nietupski JB, Budzinski T, Ziegler RJ, Yew NS, Sullivan J, Scaria A, van Rooijen N et al. (2002) Demonstration of feasibility of in vivo gene therapy for Gaucher disease using a chemically induced mouse model. Mol Ther 6:179-189.

McGovern MM, Lippa N, Bagiella E, Schuchman EH, Desnick RJ and Wasserstein MP (2013) Morbidity and mortality in type B Niemann-Pick disease. Genet Med 15:618-623.

Metcalf JA, Linders B, Wu S, Bigg P, O’Donnell P, Sleeper MM, Whyte MP, Haskins M and Ponder KP (2010) Upregulation of elastase activity in aorta in mucopolysaccharidosis I and VII dogs may be due to increased cytokine expression. Mol Genet Metab 99:396-407.

Miranda SR, Erlich S, Friedrich VL, Gatt S and Schuchman EH (2000) Hematopoietic stem cell gene therapy leads to marked visceral organ improvements and a delayed onset of neurological abnormalities in the acid sphingomyelinase deficient mouse model of Niemann-Pick disease. Gene Ther 7:1768-1776.
Morrone A, Bardelli T, Donati MA, Giorgi M, Di Rocco M, Gatti R, Parini R, Ricci R, Taddeucci G, D'Azzo A and Zammarchi E (2000) Beta-galactosidase gene mutations affecting the lysosomal enzyme and the elastin-binding protein in GM1-gangliosidosis patients with cardiac involvement. Hum Mutat 15:354-366.

Motas S, Haurigot V, Garcia M, Marco S, Ribera A, Roca C, Sanchez X, Sanchez V, Molas M, Bertolin J et al. (2016) CNS-directed gene therapy for the treatment of neurologic and somatic mucopolysaccharidosis type II (Hunter syndrome). JCI Insight 1:e86696.

Nakamura G, Maruyama H, Ishii S, Shimotori M, Kameda S, Kono T, Miyazaki J, Kulkarni AB and Gejyo F (2008) Naked plasmid DNA-based alpha-galactosidase A gene transfer partially reduces systemic accumulation of globotriaosylceramide in Fabry mice. Mol Biotechnol 38:109-119.

Ogawa K, Hirai Y, Ishizaki M, Takahashi H, Hanawa H, Fukunaga Y and Shimada T (2009) Long-term inhibition of glycosphingolipid accumulation in Fabry model mice by a single systemic injection of AAV1 vector in the neonatal period. Mol Genet Metab 96:91-96.

Oheda Y, Kotani M, Murata M, Sakuraba H, Kadota Y, Tatano Y, Kuwahara J and Itoh K (2006) Elimination of abnormal sialylglycoproteins in fibroblasts with sialidosis and galactosialidosis by normal gene transfer and enzyme replacement. Glycobiology 16:271-280.

Okamura-Oho Y, Zhang S and Callahan JW (1994) The biochemistry and clinical features of galactosialidosis. Biochim Biophys Acta 1225:244-254.

Ortolano S, Vieitez I, Navarro C and Spuch C (2014) Treatment of lysosomal storage diseases: recent patents and future strategies. Recent Pat Endocr Metab Immune Drug Discov 8:925.

Osborn MJ, McElmurry RT, Lees CJ, DeFeo AP, Chen ZY, Kay MA, Naldini L, Freeman G, Tolar J and Blazar BR (2011) Minicircle DNA-based gene therapy coupled with immune modulation permits long-term expression of alpha-Liduronidase in mice with mucopolysaccharidosis type I. Mol Ther 19:450-460.

Ou L, Przybilla MJ, Koniar BL and Whitley CB (2016) Elements of lentiviral vector design toward gene therapy for treating mucopolysaccharidosis I. Mol Genet Metab Rep 8:87-93.

Parenti G, Pignata C, Vajro P and Salerno M (2013) New strategies for the treatment of lysosomal storage diseases (review). Int J Mol Med 31:11-20.

Park J, Murray GJ, Limaye A, Quirk JM, Gelderman MP, Brady RO and Qasba P (2003) Long-term correction of globotriaosylceramide storage in Fabry mice by recombinant adeno-associated virus-mediated gene transfer. Proc Natl Acad Sci U S A 100:3450-3454.

Pauly DF, Johns DC, Matelis LA, Lawrence JH, Byrne BJ and Kessler PD (1998) Complete correction of acid alphaglucosidase deficiency in Pompe disease fibroblasts in vitro, and lysosomally targeted expression in neonatal rat cardiac and skeletal muscle. Gene Ther 5:473-480.

Pauly DF, Fraites TJ, Toma C, Bayes HS, Huie ML, Hirschhorn R, Plotz PH, Raben N, Kessler PD and Byrne BJ (2001) Intercellular transfer of the virally derived precursor form of acid alpha-glucosidase corrects the enzyme deficiency in inherited cardioskeletal myopathy Pompe disease. Hum Gene Ther 12:527-538. 
Platt FM, Boland B and van der Spoel AC (2012) The cell biology of disease: Lysosomal storage disorders: The cellular impact of lysosomal dysfunction. J Cell Biol 199:723-734.

Ponder KP, Melniczek JR, Xu L, Weil MA, O’Malley TM, O'Donnell PA, Knox VW, Aguirre GD, Mazrier H and Ellinwood NM (2002) Therapeutic neonatal hepatic gene therapy in mucopolysaccharidosis VII dogs. Proc Natl Acad Sci U S A 99:13102-13107.

Ponder KP, O'Malley TM, Wang P, O'Donnell PA, Traas AM, Knox VW, Aguirre GA, Ellinwood NM, Metcalf JA, Wang $\mathrm{B}$ et al. (2012) Neonatal gene therapy with a gamma retroviral vector in mucopolysaccharidosis VI cats. Mol Ther 20:898-907.

Przybylska M, Wu IH, Zhao H, Ziegler RJ, Tousignant JD, Desnick RJ, Scheule RK, Cheng SH and Yew NS (2004) Partial correction of the alpha-galactosidase A deficiency and reduction of glycolipid storage in Fabry mice using synthetic vectors. J Gene Med 6:85-92.

Qin G, Takenaka T, Telsch K, Kelley L, Howard T, Levade T, Deans R, Howard BH, Malech HL, Brady RO and Medin JA (2001) Preselective gene therapy for Fabry disease. Proc Natl Acad Sci U S A 98:3428-3433.

Rastall DP, Seregin SS, Aldhamen YA, Kaiser LM, Mullins C, Liou A, Ing F, Pereria-Hicks C, Godbehere-Roosa S, Palmer $\mathrm{D}$ et al. (2016) Long-term, high-level hepatic secretion of acid alpha-glucosidase for Pompe disease achieved in nonhuman primates using helper-dependent adenovirus. Gene Ther 23:743-752.

Rigante D and Segni G (2002) Cardiac structural involvement in mucopolysaccharidoses. Cardiology 98:18-20.

Salganik M, Hirsch ML and Samulski RJ (2015) Adenoassociated virus as a mammalian DNA vector. Microbiol Spectrum 3:1-21.

Sands MS and Davidson BL (2006) Gene therapy for lysosomal storage diseases. Mol Ther 13:839-849.

Schuchman EH and Wasserstein MP (2015) Types A and B Niemann-Pick disease. Best Pract Res Clin Endocrinol Metab 29:237-247.

Schuh RS, Baldo G and Teixeira HF (2016) Nanotechnology applied to treatment of mucopolysaccharidoses. Expert Opin Drug Deliv 13:1709-1718.

Segatori L (2014) Impairment of homeostasis in lysosomal storage disorders. IUBMB Life 66:472-477.

Senocak F, Sarclar M and Ozkutlu S (1994) Echocardiographic findings in some metabolic storage diseases. Jpn Heart J 35:635-643.

Sferra TJ, Backstrom K, Wang C, Rennard R, Miller M and Hu Y (2004) Widespread correction of lysosomal storage following intrahepatic injection of a recombinant adeno-associated virus in the adult MPS VII mouse. Mol Ther 10:478-491.

Sleeper MM, Fornasari B, Ellinwood NM, Weil MA, Melniczek J, O’Malley TM, Sammarco CD, Xu L, Ponder KP and Haskins ME (2004) Gene therapy ameliorates cardiovascular disease in dogs with mucopolysaccharidosis VII. Circulation 110:815-820.

Sleeper MM, Kusiak CM, Shofer FS, O’Donnell P, Bryan C, Ponder KP and Haskins ME (2008) Clinical characterization of cardiovascular abnormalities associated with feline mucopolysaccharidosis I and VI. J Inherit Metab Dis 31:424-431.

Stroncek DF, Hubel A, Shankar RA, Burger SR, Pan D, McCullough J and Whitley CB (1999) Retroviral trans- duction and expansion of peripheral blood lymphocytes for the treatment of mucopolysaccharidosis type II, Hunter's syndrome. Transfusion 39:343-350.

Sun BD, Chen YT, Bird A, Amalfitano A and Koeberl DD (2003) Long-term correction of glycogen storage disease type II with a hybrid Ad-AAV vector. Mol Ther 7:193-201.

Sun B, Zhang H, Franco LM, Brown T, Bird A, Schneider A and Koeberl DD (2005a) Correction of glycogen storage disease type II by an adeno-associated virus vector containing a muscle-specific promoter. Mol Ther 11:889-898.

Sun B, Zhang H, Franco LM, Young SP, Schneider A, Bird A, Amalfitano A, Chen YT and Koeberl DD (2005b) Efficacy of an adeno-associated virus 8-pseudotyped vector in glycogen storage disease type II. Mol Ther 11:57-65.

Sun B, Young SP, Li P, Di C, Brown T, Salva MZ, Li S, Bird A, Yan Z, Auten R, Hauschka SD and Koeberl DD (2008) Correction of multiple striated muscles in murine Pompe disease through adeno-associated virus-mediated gene therapy. Mol Ther 16:1366-1371.

Sun B, Li S, Bird A and Koeberl DD (2010) Hydrostatic isolated limb perfusion with adeno-associated virus vectors enhances correction of skeletal muscle in Pompe disease. Gene Ther 17:1500-1505.

Takahashi H, Hirai Y, Migita M, Seino Y, Fukuda Y, Sakuraba H, Kase R, Kobayashi T, Hashimoto Y and Shimada T (2002) Long-term systemic therapy of Fabry disease in a knockout mouse by adeno-associated virus-mediated muscle-directed gene transfer. Proc Natl Acad Sci U S A 99:13777-13782.

Takaura N, Yagi T, Maeda M, Nanba E, Oshima A, Suzuki Y, Yamano T and Tanaka A (2003) Attenuation of ganglioside GM1 accumulation in the brain of GM1 gangliosidosis mice by neonatal intravenous gene transfer. Gene Ther 10:14871493.

Takenaka T, Murray GJ, Qin G, Quirk JM, Ohshima T, Qasba P, Clark K, Kulkarni AB, Brady RO and Medin JA (2000) Long-term enzyme correction and lipid reduction in multiple organs of primary and secondary transplanted Fabry mice receiving transduced bone marrow cells. Proc Natl Acad Sci U S A 97:7515-7520.

Tessitore A, Faella A, O'Malley T, Cotugno G, Doria M, Kunieda T, Matarese G, Haskins M and Auricchio A (2008) Biochemical, pathological, and skeletal improvement of mucopolysaccharidosis VI after gene transfer to liver but not to muscle. Mol Ther 16:30-37.

Toietta G, Severini GM, Traversari C, Tomatsu S, Sukegawa K, Fukuda S, Kondo N, Tortora P and Bordignon C (2001) Various cells retrovirally transduced with $\mathrm{N}$-acetylgalactosoamine-6-sulfate sulfatase correct Morquio skin fibroblasts in vitro. Hum Gene Ther 12:2007-2016.

Tomanin R, Friso A, Alba S, Piller Puicher E, Mennuni C, La Monica N, Hortelano G, Zacchello F and Scarpa M (2002) Non-viral transfer approaches for the gene therapy of mucopolysaccharidosis type II (Hunter syndrome). Acta Paediatr Suppl 91:100-104.

Tomatsu S, Mackenzie WG, Theroux MC, Mason RW, Thacker MM, Shaffer TH, Montano AM, Rowan D, Sly W, Almeciga-Diaz CJ et al. (2012) Current and emerging treatments and surgical interventions for Morquio A syndrome: A review. Res Rep Endocr Disord 2012:65-77.

Tomatsu S, Yasuda E, Patel P, Ruhnke K, Shimada T, Mackenzie WG, Mason R, Thacker MM, Theroux M, Montano AM et 
al. (2014) Morquio A syndrome: Diagnosis and current and future therapies. Pediatr Endocrinol Rev 12 Suppl 1:141151.

Traas AM, Wang P, Ma X, Tittiger M, Schaller L, O’Donnell P, Sleeper MM, Vite C, Herati R, Aguirre GD et al. (2007) Correction of clinical manifestations of canine mucopolysaccharidosis I with neonatal retroviral vector gene therapy. Mol Ther 15:1423-1431.

Valayannopoulos V, Nicely H, Harmatz P and Turbeville S (2010) Mucopolysaccharidosis VI. Orphanet J Rare Dis 5:5.

van Til NP, Stok M, Aerts Kaya FS, de Waard MC, Farahbakhshian E, Visser TP, Kroos MA, Jacobs EH, Willart MA et al. (2010) Lentiviral gene therapy of murine hematopoietic stem cells ameliorates the Pompe disease phenotype. Blood 115:5329-5337.

Venugopalan P and Joshi SN (2002) Cardiac involvement in infantile Sandhoff disease. J Pediatr Child Health 38:98-100.

Visigalli I, Delai S, Politi LS, Di Domenico C, Cerri F, Mrak E, D'Isa R, Ungaro D, Stok M, Sanvito F et al. (2010) Gene therapy augments the efficacy of hematopoietic cell transplantation and fully corrects mucopolysaccharidosis type I phenotype in the mouse model. Blood 116:5130-5139.

Wakabayashi T, Shimada Y, Akiyama K, Higuchi T, Fukuda T, Kobayashi H, Eto Y, Ida H, and Ohashi T (2015) Hematopoietic stem cell gene therapy corrects neuropathic phenotype in murine model of Mucopolysaccharidosis Type II. Hum Gene Ther 26:357-366.

Wang D and Gao G (2014) State-of-the-art human gene therapy: Part I. Gene delivery technologies. Discov Med 18:67-77.

Wang G, Young SP, Bali D, Hutt J, Li S, Benson J and Koeberl DD (2014) Assessment of toxicity and biodistribution of recombinant AAV8 vector-mediated immunomodulatory gene therapy in mice with Pompe disease. Mol Ther Methods Clin Dev 1:14018.

Wang W, Li W, Ma N and Steinhoff G (2013) Non-viral gene delivery methods. Curr Pharmaceut Biotechnol 14:46-60.

Watson JG, Gardner-Medwin D, Goldfinch ME and Pearson AD (1986) Bone marrow transplantation for glycogen storage disease type II (Pompe's disease). N Engl J Med 314:385.

Weismann CM, Ferreira J, Keeler AM, Su Q, Qui L, Shaffer SA, $\mathrm{Xu} \mathrm{Z}, \mathrm{Gao} \mathrm{G}$ and Sena-Esteves M (2015) Systemic AAV9 gene transfer in adult GM1 gangliosidosis mice reduces lysosomal storage in CNS and extends lifespan. Hum Mol Genet 24:4353-4364.

Wens SC, Kuperus E, Mattace-Raso FU, Kruijshaar ME, Brusse E, van Montfort KC, de Boer MS, Sijbrands EJ, van der Ploeg AT and van Doorn PA (2014) Increased aortic stiffness and blood pressure in non-classic Pompe disease. J Inherit Metab Dis 37:391-397.

Whitley CB, McIvor RS, Aronovich EL, Berry SA, Blazar BR, Burger SR, Kersey JH, King RA, Faras AJ, Latchaw RE et al. (1996) Retroviral-mediated transfer of the iduronate2-sulfatase gene into lymphocytes for treatment of mild Hunter syndrome (mucopolysaccharidosis type II). Hum Gene Ther 7:537-549.

Wold WS and Toth K (2013) Adenovirus vectors for gene therapy, vaccination and cancer gene therapy. Curr Gene Ther 13:421-433.

Wu Z, Asokan A and Samulski RJ (2006) Adeno-associated virus serotypes: vector toolkit for human gene therapy. Mol Ther 14:316-327.
Xu F, Ding E, Liao SX, Migone F, Dai J, Schneider A, Serra D, Chen YT and Amalfitano A (2004) Improved efficacy of gene therapy approaches for Pompe disease using a new, immune-deficient GSD-II mouse model. Gene Ther 11:15901598.

Xu F, Ding E, Migone F, Serra D, Schneider A, Chen YT and Amalfitano A (2005) Glycogen storage in multiple muscles of old GSD-II mice can be rapidly cleared after a single intravenous injection with a modified adenoviral vector expressing hGAA. J Gene Med 7:171-178.

Xu L, Mango RL, Sands MS, Haskins ME, Ellinwood NM and Ponder KP (2002) Evaluation of pathological manifestations of disease in mucopolysaccharidosis VII mice after neonatal hepatic gene therapy. Mol Ther 6:745-758.

Yoshimitsu M, Higuchi K, Dawood F, Rasaiah VI, Ayach B, Chen M, Liu P and Medin JA (2006) Correction of cardiac abnormalities in fabry mice by direct intraventricular injection of a recombinant lentiviral vector that engineers expression of alpha-galactosidase A. Circulation J 70:1503-1508.

Yoshimitsu M, Sato T, Tao K, Walia JS, Rasaiah VI, Sleep GT, Murray GJ, Poeppl AG, Underwood J, West L et al. (2004) Bioluminescent imaging of a marking transgene and correction of Fabry mice by neonatal injection of recombinant lentiviral vectors. Proc Natl Acad Sci U S A 101:1690916914.

Yoshimitsu M, Higuchi K, Ramsubir S, Nonaka T, Rasaiah VI, Siatskas C, Liang SB, Murray GJ, Brady RO and Medin JA (2007) Efficient correction of Fabry mice and patient cells mediated by lentiviral transduction of hematopoietic stem/progenitor cells. Gene Ther 14:256-265.

Zhang H, Yang B, Mu X, Ahmed SS, Su Q, He R, Wang H, Mueller C, Sena-Esteves M, Brown R et al. (2011) Several rAAV vectors efficiently cross the blood-brain barrier and transduce neurons and astrocytes in the neonatal mouse central nervous system. Mol Ther 19:1440-1448.

Zhou XY, Morreau H, Rottier R, Davis D, Bonten E, Gillemans N, Wenger D, Grosveld FG, Doherty P, Suzuki K et al. (1995) Mouse model for the lysosomal disorder galactosialidosis and correction of the phenotype with overexpressing erythroid precursor cells. Genes Dev 9:2623-2634.

Ziegler RJ, Yew NS, Li C, Cherry M, Berthelette P, Romanczuk H, Ioannou YA, Zeidner KM, Desnick RJ and Cheng SH (1999) Correction of enzymatic and lysosomal storage defects in Fabry mice by adenovirus-mediated gene transfer. Hum Gene Ther 10:1667-1682.

Ziegler RJ, Li C, Cherry M, Zhu Y, Hempel D, van Rooijen N, Ioannou YA, Desnick RJ, Goldberg MA, Yew NS et al. (2002) Correction of the nonlinear dose response improves the viability of adenoviral vectors for gene therapy of Fabry disease. Hum Gene Ther 13:935-945.

Ziegler RJ, Lonning SM, Armentano D, Li C, Souza DW, Cherry M, Ford C, Barbon CM, Desnick RJ, Gao G et al. (2004) AAV2 vector harboring a liver-restricted promoter facilitates sustained expression of therapeutic levels of alphagalactosidase $\mathrm{A}$ and the induction of immune tolerance in Fabry mice. Mol Ther 9:231-240.

Ziegler RJ, Cherry M, Barbon CM, Li C, Bercury SD, Armentano D, Desnick RJ and Cheng SH (2007) Correction of the biochemical and functional deficits in fabry mice following AAV8-mediated hepatic expression of alpha-galactosidase A. Mol Ther 15:492-500. 
Ziegler RJ, Bercury SD, Fidler J, Zhao MA, Foley J, Taksir TV, Ryan S, Hodges BL, Scheule RK, Shihabuddin LS and Cheng SH (2008) Ability of adeno-associated virus serotype 8-mediated hepatic expression of acid alpha-glucosidase to correct the biochemical and motor function deficits of presymptomatic and symptomatic Pompe mice. Hum Gene Ther 19:609-621.

Associate Editor: Mariluce Riegel

License information: This is an open-access article distributed under the terms of the Creative Commons Attribution License (type CC-BY), which permits unrestricted use, distribution and reproduction in any medium, provided the original article is properly cited. 